US Army Corps

of Engineers $s_{\circledast}$

Engineer Research and

Development Center

\title{
Brunswick Harbor Numerical Model
}

Jennifer McAlpin and Jason Lavecchia

May 2021 
The US Army Engineer Research and Development Center (ERDC) solves the nation's toughest engineering and environmental challenges. ERDC develops innovative solutions in civil and military engineering, geospatial sciences, water resources, and environmental sciences for the Army, the Department of Defense, civilian agencies, and our nation's public good. Find out more at www.erdc.usace.army.mil.

To search for other technical reports published by ERDC, visit the ERDC online library at https://erdclibrary.on.worldcat.org/discovery. 


\title{
Brunswick Harbor Numerical Model
}

\author{
Jennifer McAlpin \\ Coastal and Hydraulics Laboratory \\ US Army Engineer Research and Development Center \\ 3909 Halls Ferry Road \\ Vicksburg, MS 39180-6199 \\ Jason Lavecchia \\ USACE District, Savannah (SAS) \\ 101 W York St. \\ Savannah, GA 31401
}

Final report

Approved for public release; distribution is unlimited.
Prepared for USACE District, Savannah
Savannah, GA 31401
Under Project P2 465055, Funding Account Code K6219288, AMSCO Code 465055, MIPR W33SJG92845079




\section{Abstract}

The Brunswick area consists of many acres of estuarine and marsh environments. The US Army Corps of Engineers District, Savannah, requested that the US Army Engineer Research and Development Center, Coastal and Hydraulics Laboratory, develop a validated Adaptive Hydraulics model and assist in using it to perform hydrodynamic modeling of proposed navigation channel modifications. The modeling results are necessary to provide data for ship simulation. The model setup and validation are presented here.

DISCLAIMER: The contents of this report are not to be used for advertising, publication, or promotional purposes. Citation of trade names does not constitute an official endorsement or approval of the use of such commercial products. All product names and trademarks cited are the property of their respective owners. The findings of this report are not to be construed as an official Department of the Army position unless so designated by other authorized documents. 


\section{Contents}

Abstract................................................................................................................ ii

Figures and Tables.............................................................................................iv

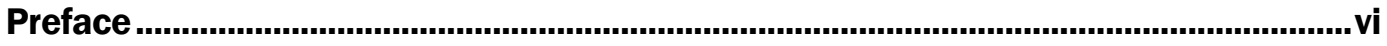

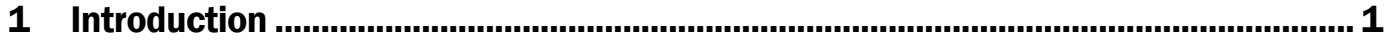

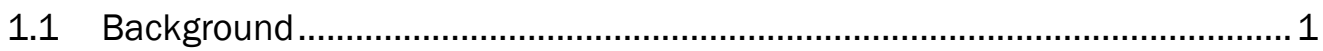

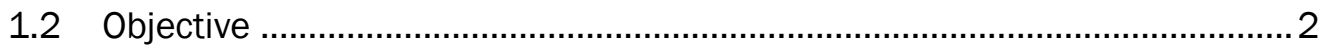

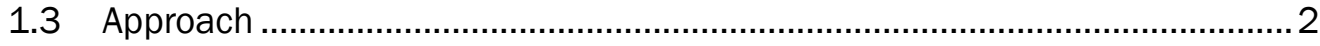

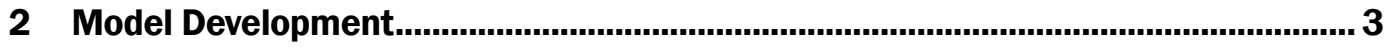

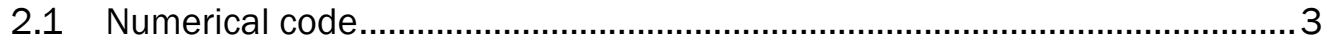

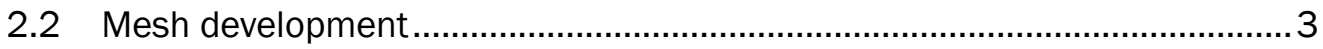

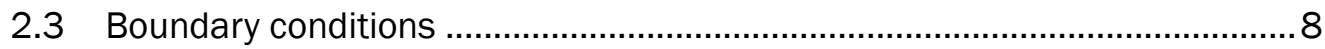

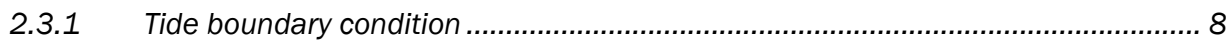

2.3.2 Meteorological input (wind) .......................................................................... 10

2.3.3 AdH model parameters................................................................................... 11

3 Model/Field Comparison .............................................................................................14

3.1 Field data collection ....................................................................... 14

3.2 Hydrodynamic comparisons.............................................................15

3.2.1 Water surface elevation..................................................................................... 15

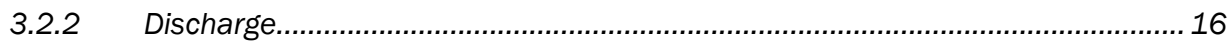

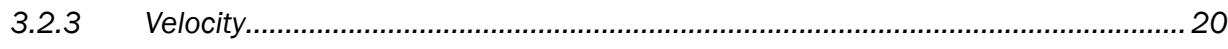

4 Conclusions .............................................................................................................. 27

References......................................................................................................................... 28

Report Documentation Page 


\section{Figures and Tables}

\section{Figures}

Figure 1. Brunswick harbor location map....................................................................... 1

Figure 2. Areas of proposed channel modification (circled)................................................... 2

Figure 3. USACE-collected bathymetry. .......................................................................... 4

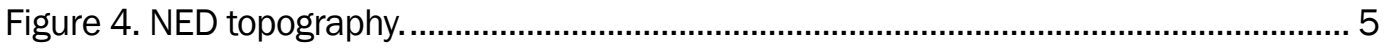

Figure 5. CRM bathymetry/topography. ........................................................................ 5

Figure 6. Model domain bathymetry........................................................................... 6

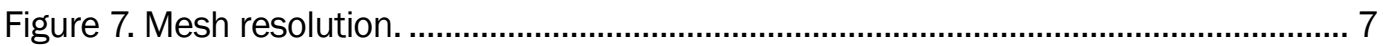

Figure 8. Brunswick Navigation Channel mesh resolution. ................................................ 8

Figure 9. St. Simons Island tide gage location. ................................................................... 9

Figure 10. St. Simons Island data adjustment for tide boundary condition $(0 \mathrm{hr}=$

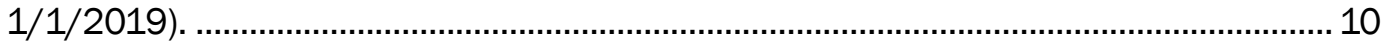

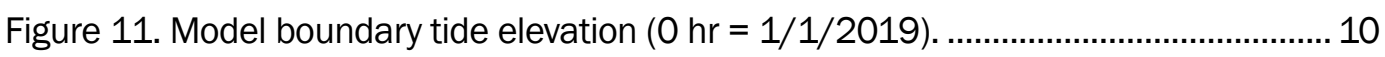

Figure 12. St. Simons Island wind speed components................................................... 11

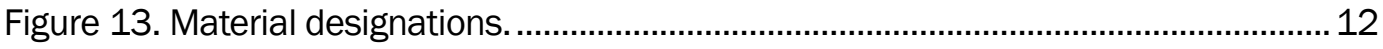

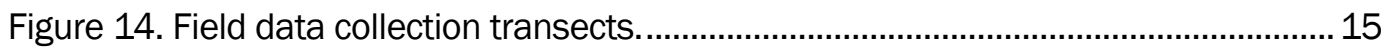

Figure 15. Water surface elevation comparison at St. Simons Island............................... 16

Figure 16. Discharge comparison at transect 1............................................................... 17

Figure 17. Discharge comparison at transect 2 ............................................................ 17

Figure 18. Discharge comparison at transect 3............................................................. 18

Figure 19. Discharge comparison at transect 4............................................................. 18

Figure 20. Discharge comparison at transect 5 ........................................................... 19

Figure 21. Discharge comparison at transect 6............................................................... 19

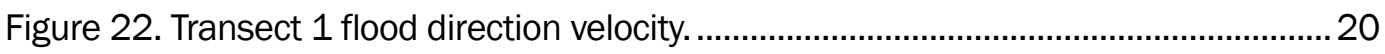

Figure 23. Transect 1 ebb direction velocity................................................................ 21

Figure 24. Transect 2 flood direction velocity. ....................................................................... 21

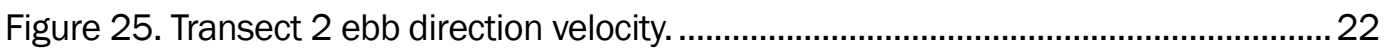

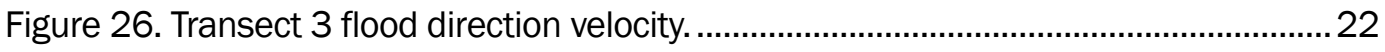

Figure 27. Transect 3 ebb direction velocity......................................................................... 23

Figure 28. Transect 4 flood direction velocity................................................................... 23

Figure 29. Transect 4 ebb direction velocity....................................................................... 24

Figure 30. Transect 5 flood direction velocity................................................................. 24

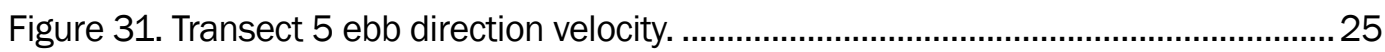

Figure 32. Transect 6 flood direction velocity................................................................. 25

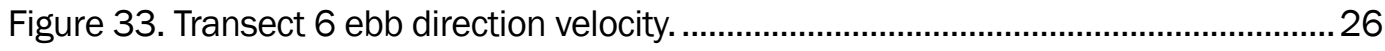




\section{Tables}

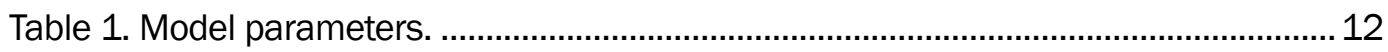

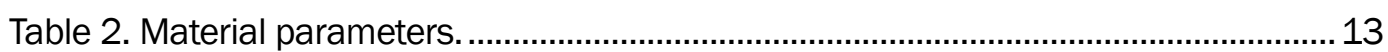




\section{Preface}

The model investigation presented in this report was authorized and funded by the US Army Corps of Engineers, Savannah District, under Project P2 465055, Funding Account Code K6219288, AMSCO Code 465055, MIPR W33SJG92845079.

The work was performed at the US Army Engineer Research and Development Center, Coastal and Hydraulics Laboratory (ERDC-CHL), Vicksburg, MS. Direct supervision was provided by Dr. Cary A. Talbot, Chief, Flood and Storm Protection Division, and Mr. David P. May, Chief, River and Estuarine Engineering Branch.

At the time of publication of this report, Mr. Keith Flowers was Deputy Director, ERDC-CHL, and Dr. Ty V. Wamsley was Director.

COL Teresa Schlosser was Commander of ERDC, and Dr. David W. Pittman was Director. 


\section{Introduction}

\subsection{Background}

Brunswick Navigation Channel and Harbor is used primarily for the import of new vehicles by Roll On - Roll Off (Ro/Ro) ships. Additionally, cargo ships transport wood and agricultural products through the Brunswick channels. The harbor is located on the southeast Georgia coast of the United States (Figure 1).

Figure 1. Brunswick harbor location map.

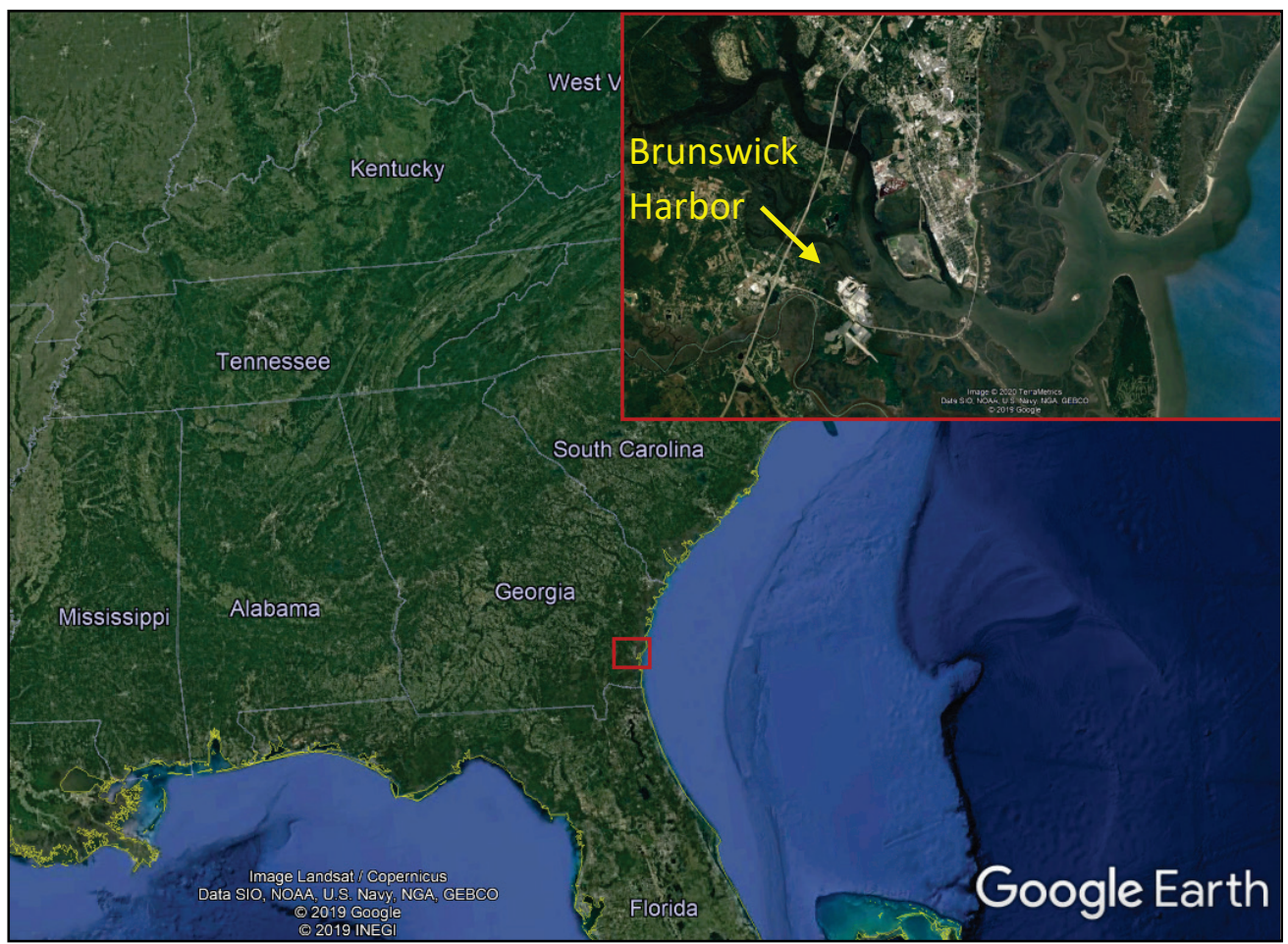

A physical model of shoaling in the area was documented in 1981 (Letter and McAnally 1981). Recently, studies of dredge material disposal use and bird habitat have been performed by the US Army Engineer Research and Development Center (ERDC), Environmental Laboratory (Guilfoyle and Fischer 2011). However, there is no documentation of recent studies of the navigation in the channels and harbor area. Cargo vessels continuously grow in size, straining the navigation channels they use to reach port. The Brunswick Harbor area receives large Ro/Ro ships transporting new vehicles. These vessels are required to make a sharp turn after entering the 
channel and then turn to back into the port (Figure 2). Simulating these maneuvers through a modeling effort will allow ship pilots to determine appropriate conditions for transit of various vessel characteristics.

Figure 2. Areas of proposed channel modification (circled).

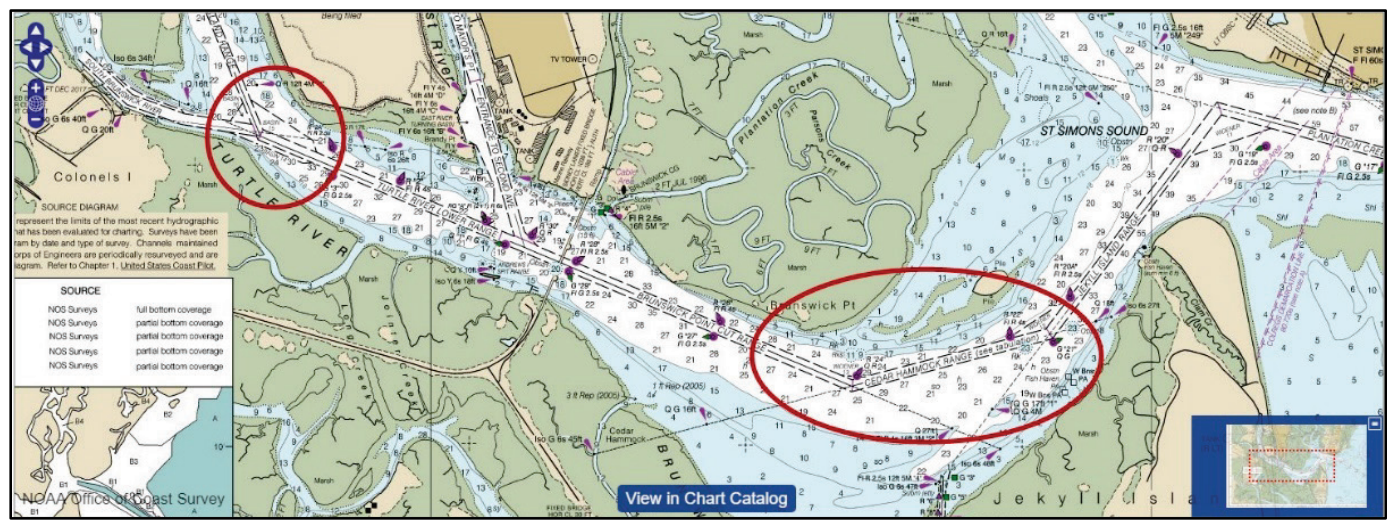

\subsection{Objective}

Ship pilots have brought up concerns about the ease of transit in some reaches of the navigation channel. The Savannah district of the United States Army Corps of Engineers (USACE) requested that the ERDC Coastal and Hydraulics Laboratory (CHL) build and validate a hydrodynamic model of the area and assist district engineers in running the model for proposed channel modifications. The modeling results are necessary for ship simulation testing at the ERDC Ship-Tow Simulator. The model setup and validation are documented.

\subsection{Approach}

A two-dimensional (2D) Adaptive Hydraulics (AdH) model was developed and validated for simulation of hydrodynamics - water surface elevation and velocity. The model was validated to available field data for all parameters and then utilized to test project alternatives. A field data collection effort was performed in July 2019 to collect discharge/velocity data at several locations.

Chapter 2 discusses the model development and boundary condition definitions for the hydrodynamic model. Chapter 3 documents the model-to-field data comparisons for water surface elevation, velocity, and discharge. Chapter 4 provides the conclusions of this numerical model investigation. 


\section{Model Development}

A numerical model was developed to analyze potential modifications of the Brunswick Navigation Channel. The model was developed such that the natural driving forces of the system are included - winds, tides, and friction effects. The model results are compared to field data collected during the simulation period to ensure an accurate representation of the conditions in the navigation channel.

\subsection{Numerical code}

AdH is the numerical model code applied for the simulations in this study (Savant et al. 2014; Savant and Berger 2015). AdH is a finite element code that is capable of simulating three-dimensional (3D) Navier-Stokes equations, 2D and 3D shallow water equations, and groundwater equations. AdH can be used in a serial or multiprocessor mode on personal computers and high-performance computing systems. AdH can refine the domain mesh in areas where more resolution is needed at certain times due to changes in the flow conditions and then remove the added resolution when it is no longer needed to minimize computational burden. The code also includes automatic time-step adaption, as needed. AdH can simulate the transport of conservative constituents such as dye clouds and sediment transport when used with SEDLIB, which is coupled to bed and hydrodynamic changes. This code has been applied to model riverine flow (Bell et al. 2017; Clifton et al. 2017) estuarine circulation (Tate et al. 2009; McAlpin et al. 2013), and sediment transport (Sharp et al. 2013; Heath et al. 2015; Letter et al. 2015).

For this study, the 2D shallow water module of AdH is applied for all simulations. This code solves for depth and depth-averaged velocity throughout the model domain (more details of the 2D shallow water module of AdH and its computational philosophy and equations are available in Savant et al. [2014] and Savant and Berger [2015]). AdH version 4.6 was applied for this study.

\subsection{Mesh development}

The model domain was determined using aerial images and bathymetric/topographic data for the area. The Surface Water Modeling System was used to generate a 2D surface mesh and define material 
regions for applying specific model features, such as bed roughness. The domain is defined horizontally in Universal Transverse Mercator, zone 17 coordinates with units of meters. Vertically, it is based on NAVD88 units of meters. All data applied to the model are adjusted to this datum and coordinate system.

Bathymetry data for the model were obtained from several sources: sponsor-collected hydrographic surveys (Figure 3), the National Elevation Dataset (NED) (Figure 4) and the Coastal Relief Model (CRM) (Figure 5). These data sets were combined such that the latest data were made a priority as well as data collected at finer resolution. The 2D AdH code can include areas that wet/dry; therefore, elevations were included that do not remain wet during the simulation period.

Figure 3. USACE-collected bathymetry.

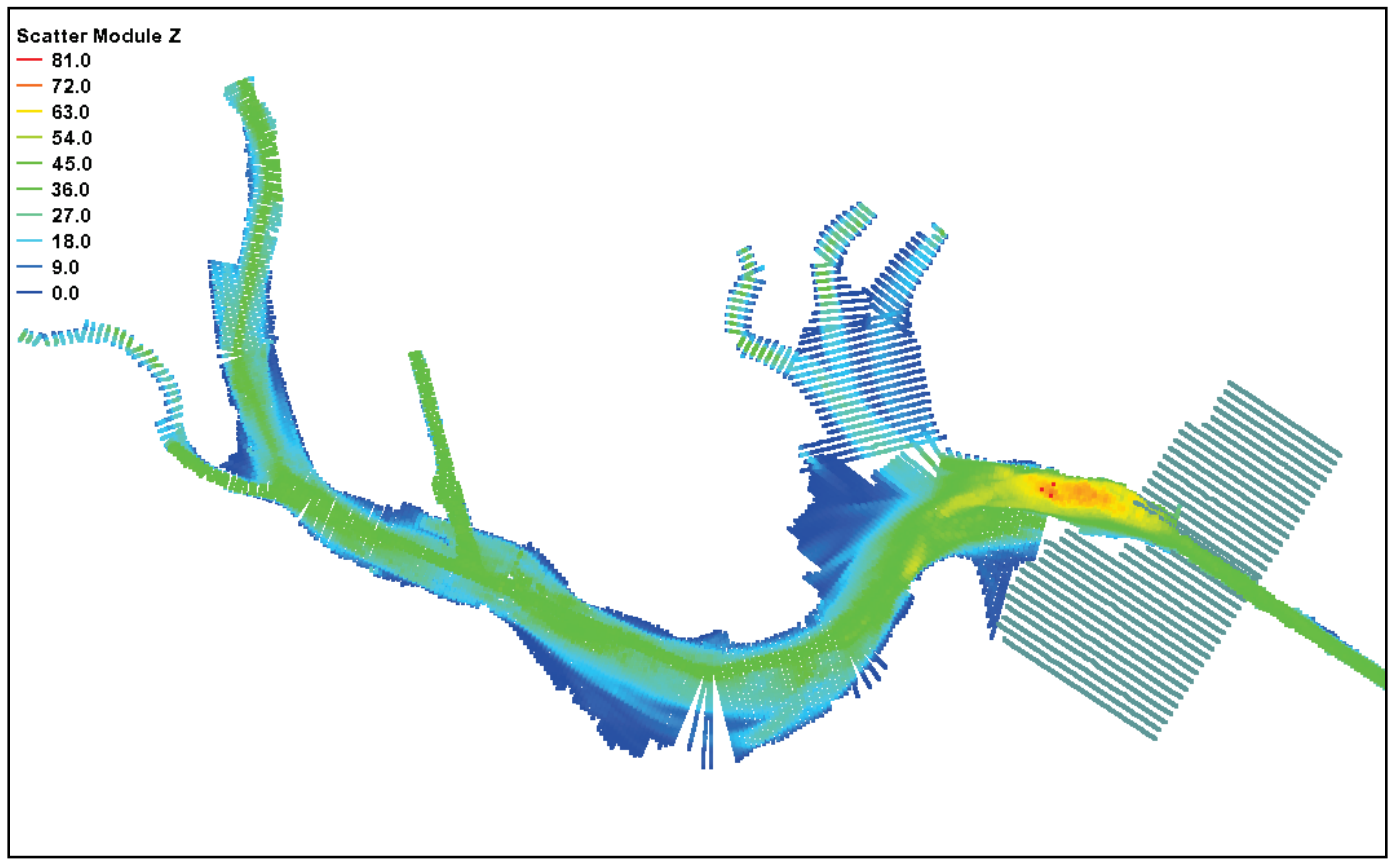


Figure 4. NED topography.

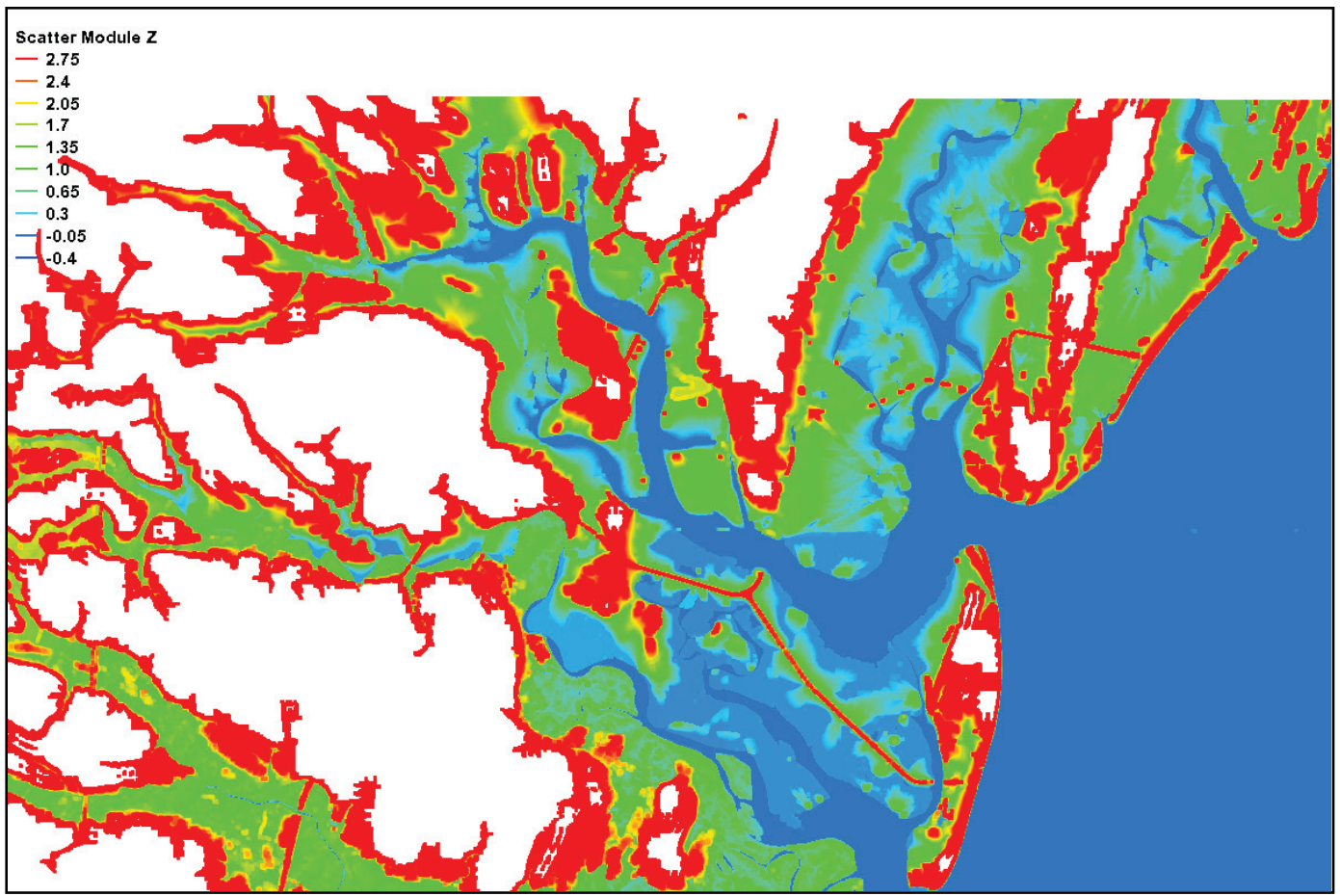

Figure 5. CRM bathymetry/topography.

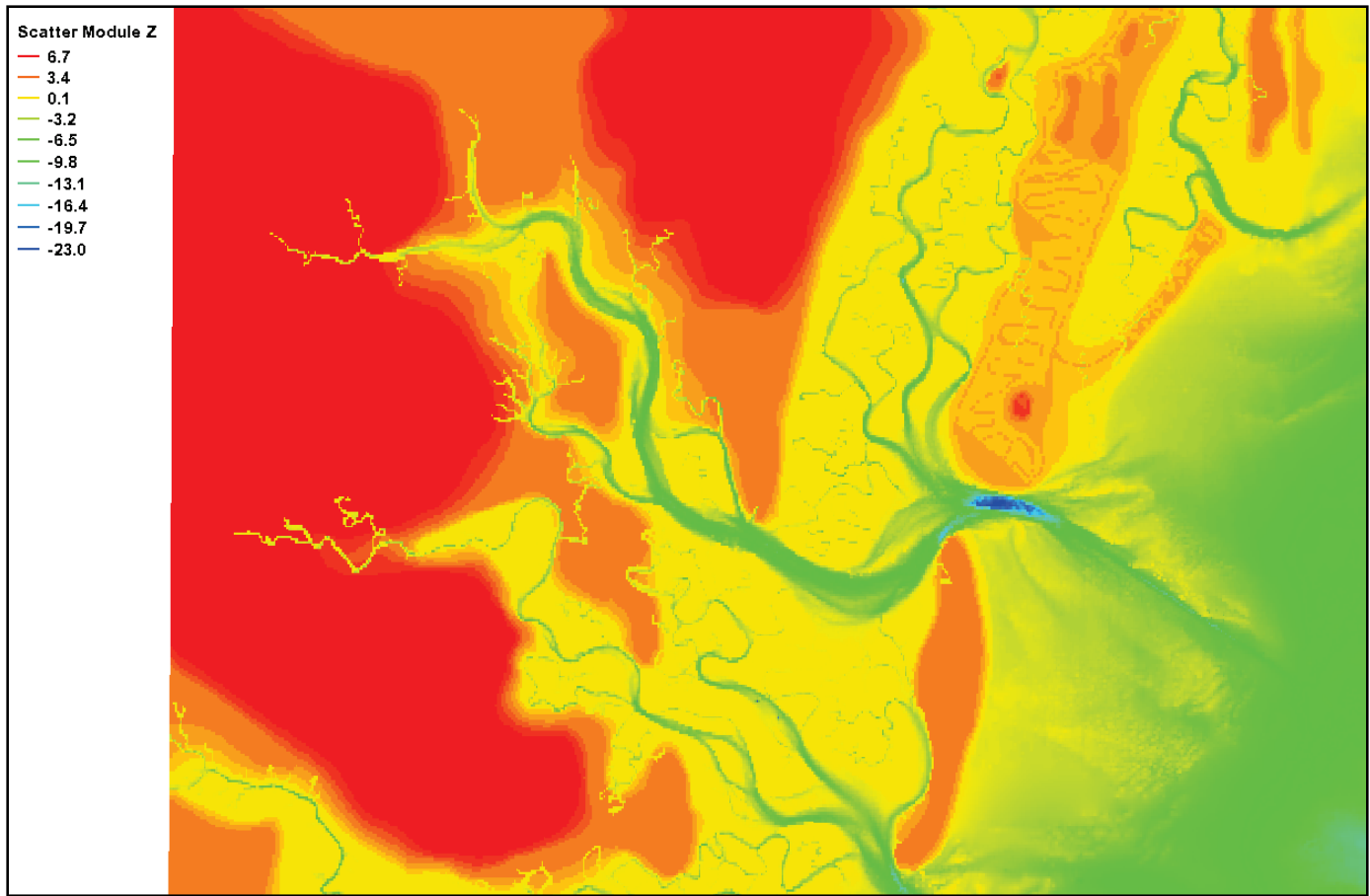


The model domain extents were based on aerial images and indicators of channel connectivity. This region is extremely marshy making accurate inclusion of tidal storage necessary to correctly represent the tidal exchange and velocity patterns. Sensitivity testing was performed on the domain size to ensure that the full area of influence was accounted for in the model. Figure 6 shows the model domain and bathymetry.

Figure 6. Model domain bathymetry.

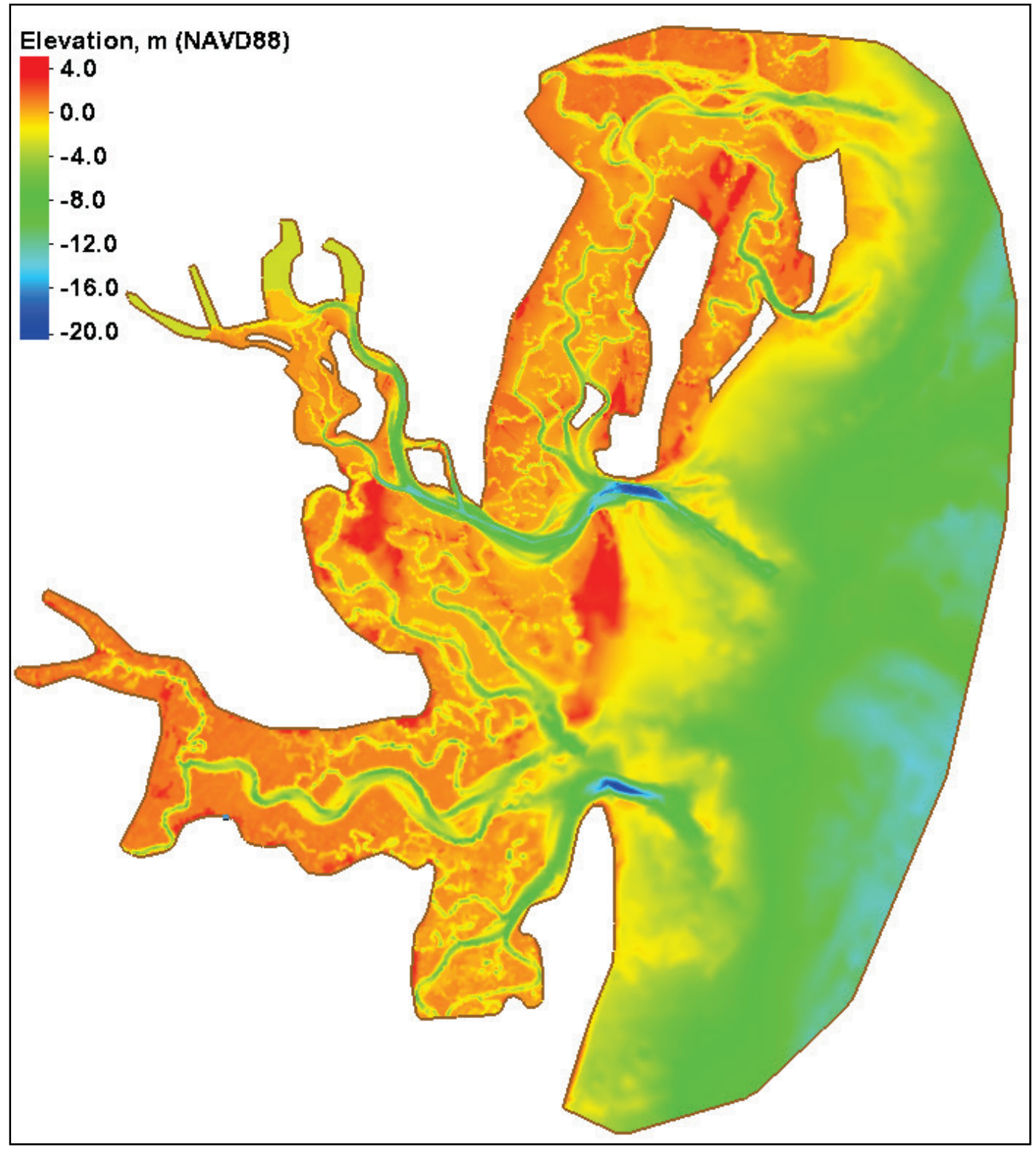


The model domain includes approximately $620 \mathrm{mi}^{2},,^{1,2}$ extending $36.75 \mathrm{mi}$ along the southern Georgia, Atlantic Ocean coastline. The 2D mesh contains 108,392 elements and 55,444 nodes. Figure 7 shows the horizontal mesh resolution for the model domain with a close-up image of the Brunswick Navigation Channel in Figure 8. Resolution is finest in the small wetland channels to accurately capture the conveyance of flow in these areas. Finer resolution is also seen in areas where geometric features need to be defined accurately, such as in the navigation channel.

Figure 7. Mesh resolution.

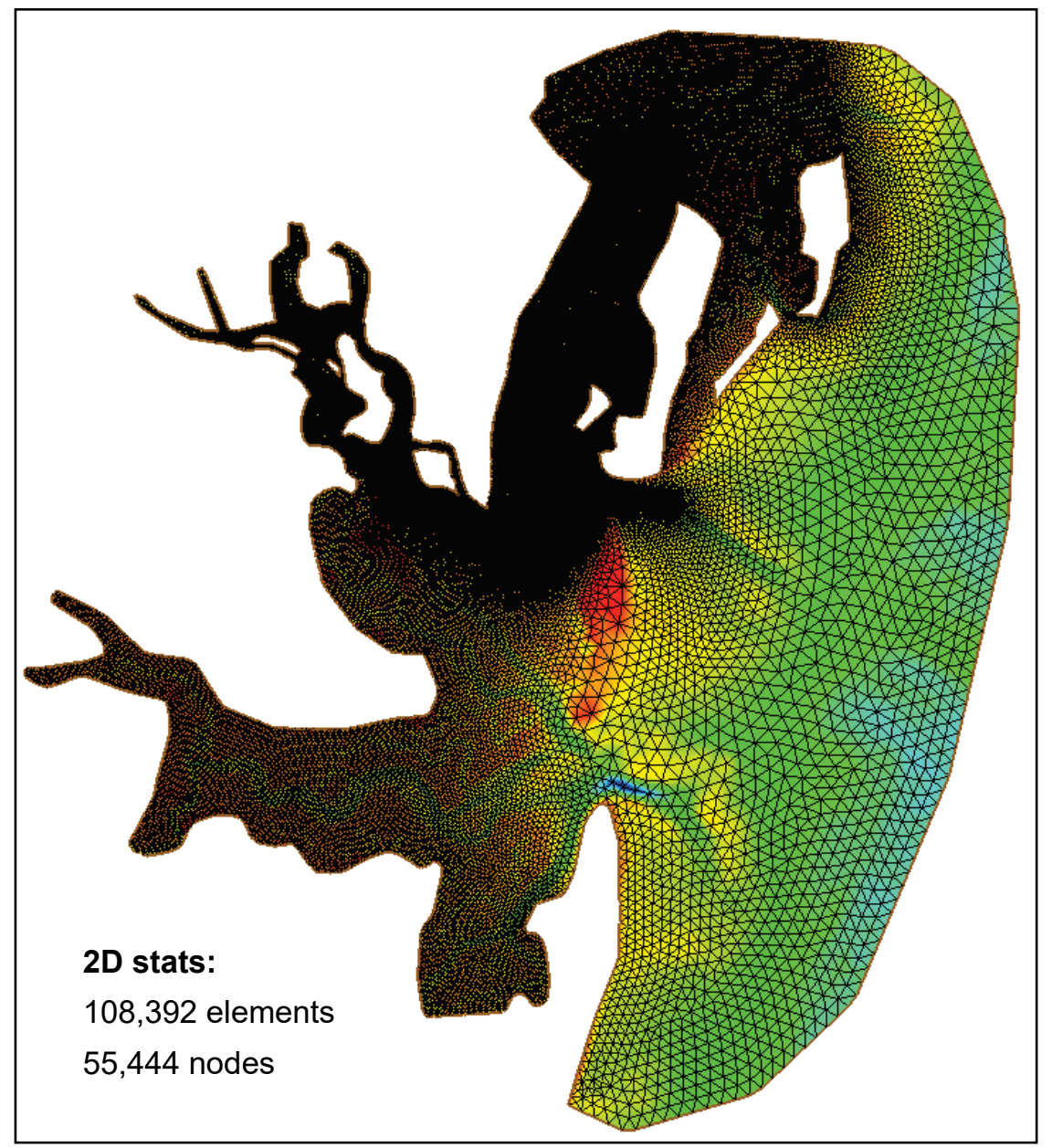

\footnotetext{
1 For a full list of the spelled-out forms of the units of measure used in this document, please refer to US Government Publishing Office Style Manual, 31st ed. (Washington, DC: US Government Publishing Office 2016), 248-52, https://www.govinfo.gov/content/pkg/GPO-STYLEMANUAL-2016/pdf/GPOSTYLEMANUAL-2016.pdf.

2 For a full list of the unit conversions used in this document, please refer to US Government Publishing Office Style Manual, 31st ed. (Washington, DC: US Government Publishing Office 2016), 345-7, https://www.govinfo.gov/content/pkg/GPO-STYLEMANUAL-2016/pdf/GPO-STYLEMANUAL-2016.pdf.
} 
Figure 8. Brunswick Navigation Channel mesh resolution.

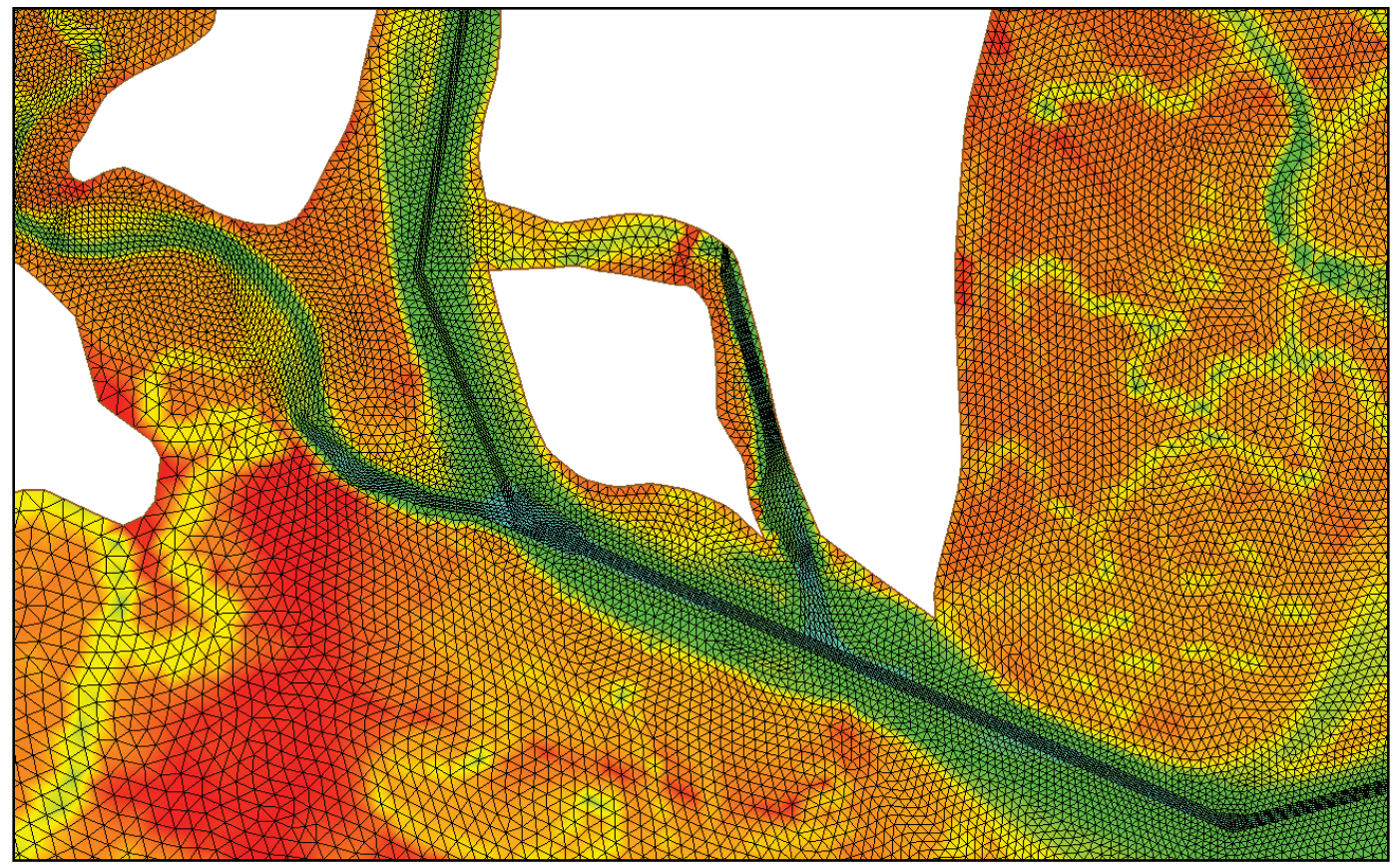

\subsection{Boundary conditions}

The boundary conditions for this study are set up in the typical manner for a numerical model study of this kind. Tidal water surface elevations are applied at the ocean boundary. Winds are included throughout the model domain. Since this area is predominantly a tidal storage region, riverine flow is extremely small and therefore not included in this model. The field data collection effort occurred in mid-July 2019; therefore, the model simulates the period 8-20 July 2019. The ship simulation will use steady state periods of maximum flood and ebb conditions that occurred during the simulation period. Note that this is not the peak period of maximum spring tide for this area. The typical maximum peak tide range is approximately $1.5 \mathrm{~m}$ higher than the maximum tide range during this simulation period. The velocity magnitudes will be larger during the maximum peak tide range period. This difference should be considered when performing ship simulation as the vessels will, at times, experience larger velocity magnitudes than those being tested with these results.

\subsubsection{Tidal boundary condition}

The tidal boundary condition was created using the US Geological Survey (USGS) gage at St. Simons Island at the inlet of the Brunswick River (Figure 9). Since this location is not at the model boundary, adjustments 
to the water level time series are made to account for any phase or amplitude changes that occur as the tide travels from the boundary to the gage location. For this model, the St. Simons Island elevation was shifted in time $-0.5 \mathrm{hr}$ and reduced in amplitude by $1.2 \%$ (Figure 10). The boundary tide elevation for the full simulation period is given in Figure 11.

Figure 9. St. Simons Island tide gage location.

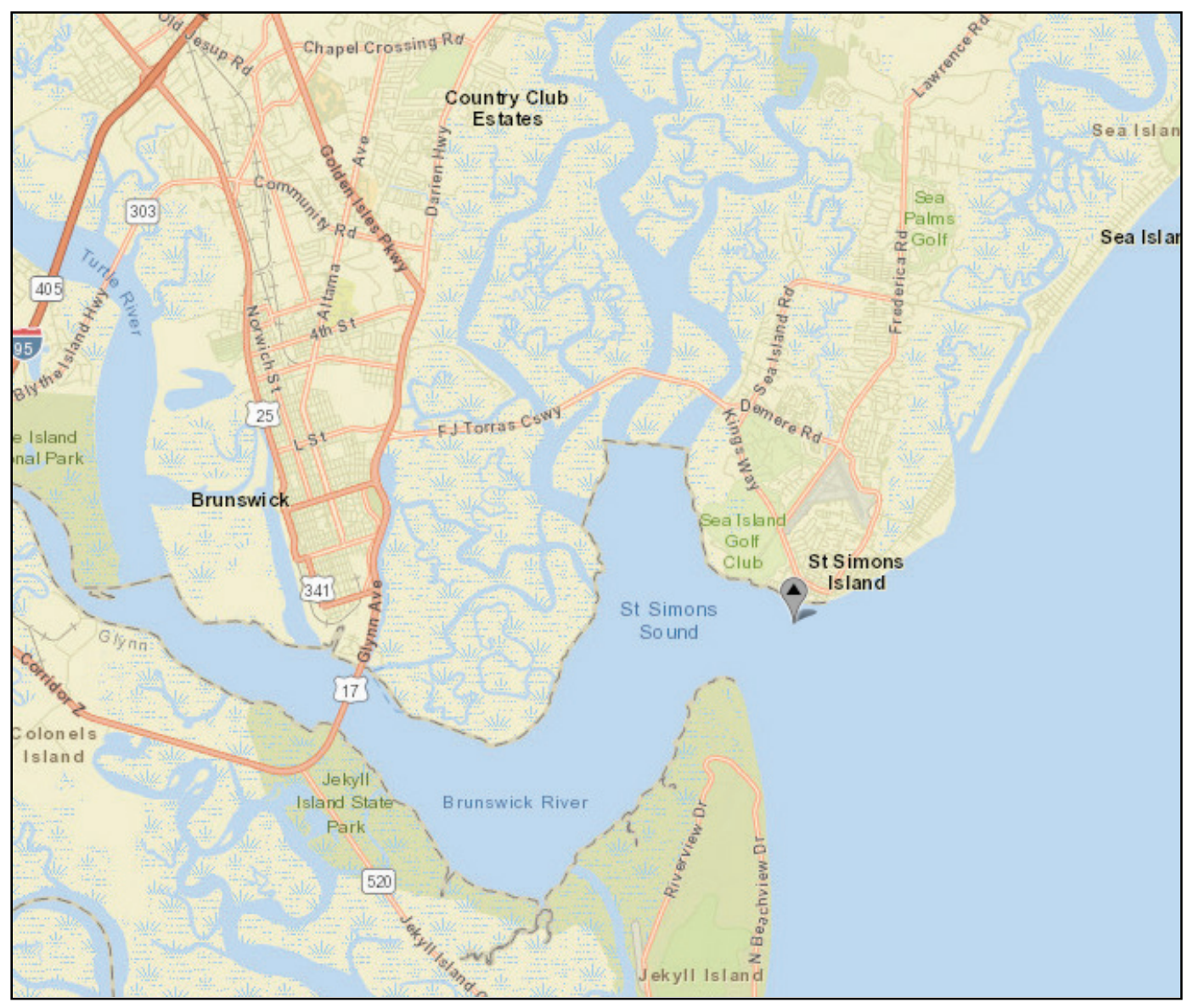


Figure 10. St. Simons Island data adjustment for tide boundary condition $(0 \mathrm{hr}=1 / 1 / 2019)$.

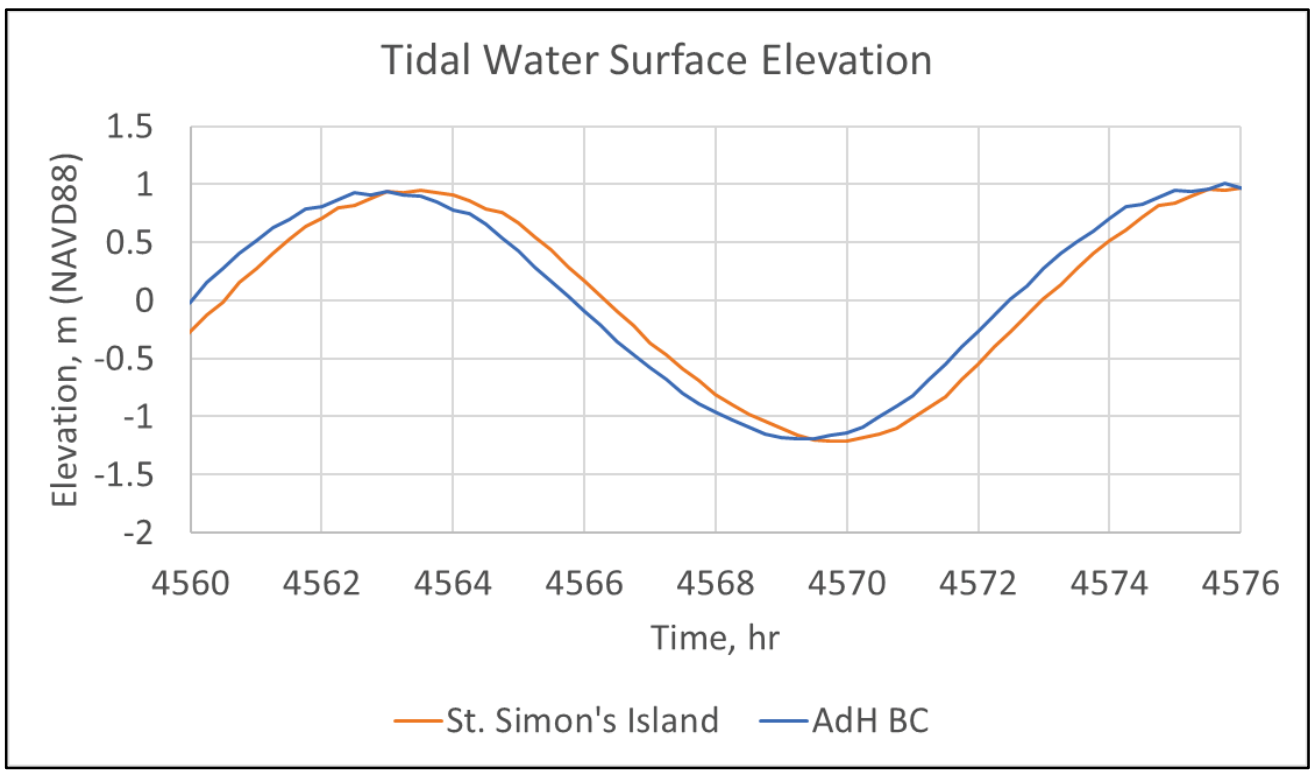

Figure 11. Model boundary tide elevation $(0 \mathrm{hr}=1 / 1 / 2019)$.

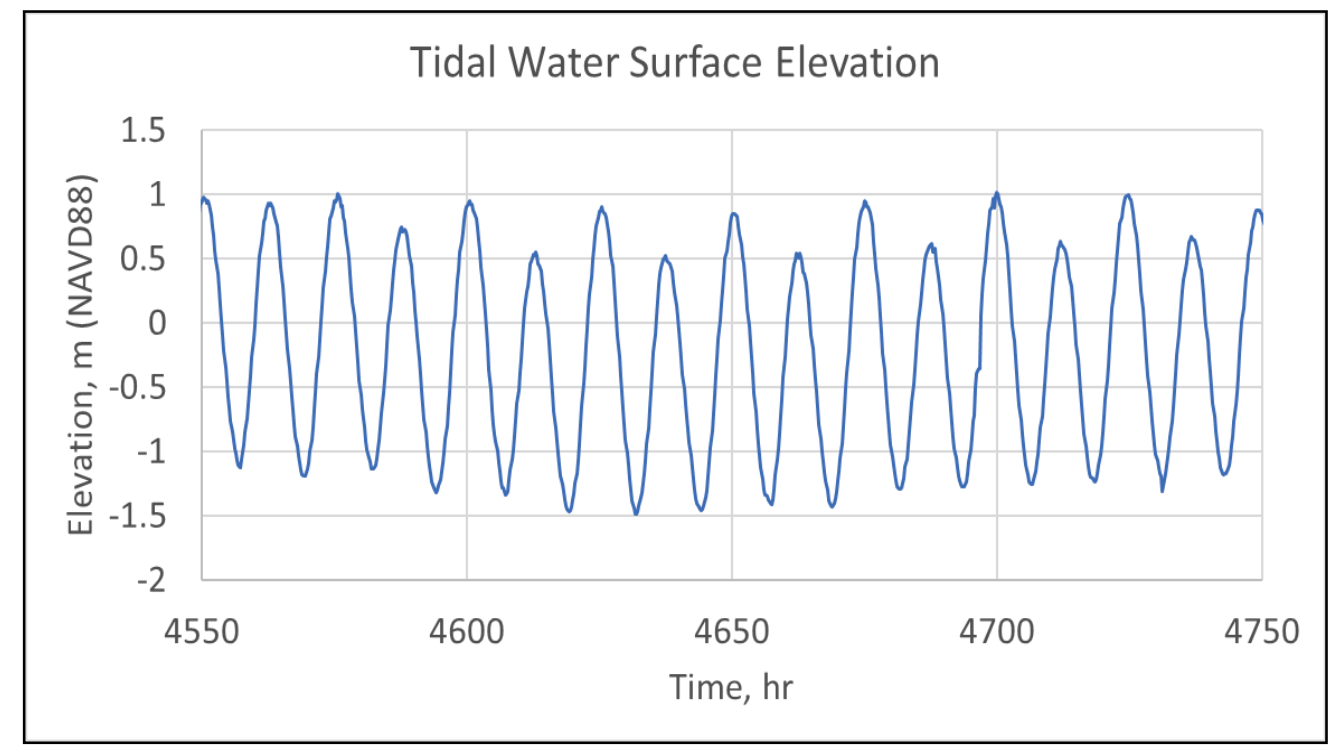

\subsubsection{Meteorological input (wind)}

Wind data were available from the USGS collection site at St. Simons Island (Figure 9). The wind speed and direction were converted to Cartesian components. This process included shifting the direction from meteorological format. Figure 12 shows the Cartesian wind speed components with direction converted to "blowing toward" measured counter-clockwise from east. 
Figure 12. St. Simons Island wind speed components.

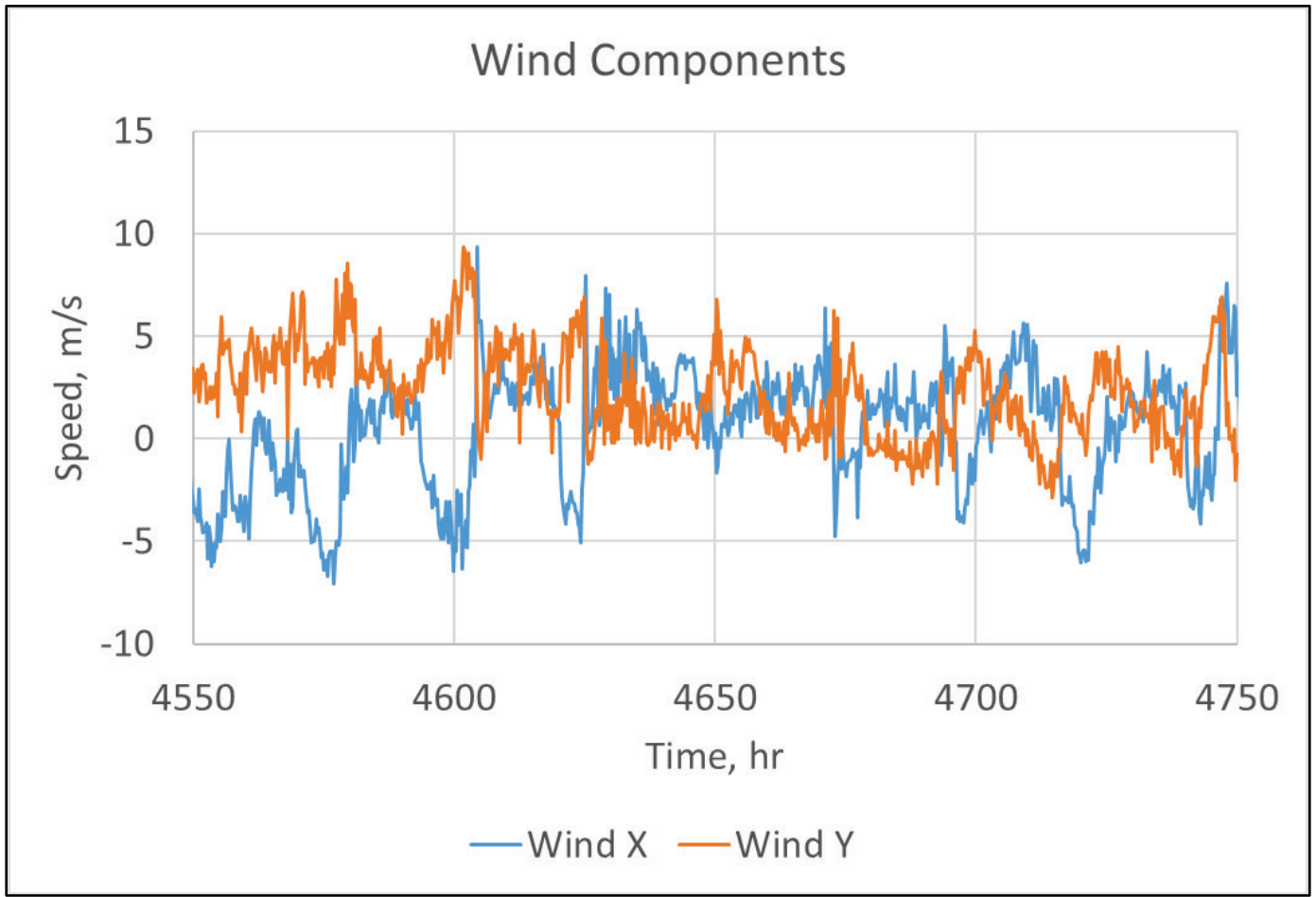

The AdH code can use supplied wind stress components or wind speed and direction to compute the wind stress internally. In this model, the $\mathrm{Wu}$ formulation (Wu 1982) is used in the ocean and inlet areas - the deeper areas of the domain. The Teeter formulation (Teeter 2002) is used in the shallow wetland areas.

\subsubsection{AdH model parameters}

The parameters used by AdH to achieve the validated model (discussed in the following sections) are provided in Table 1. This table provides the specific values used for various model properties such as convergence, eddy viscosity, and time step. The values can vary by location as defined in Figure 13, although in this model only the wind formulation and bed roughness were varied by material as shown in Table 2 . 
Table 1. Model parameters.

\begin{tabular}{|c|c|c|}
\hline \multicolumn{2}{|l|}{ Parameter } & Value \\
\hline \multicolumn{2}{|c|}{ Estimated Eddy Viscosity Coefficient } & 0.5 (Isotropic) \\
\hline \multicolumn{2}{|c|}{ Wetting/Drying Tolerance } & $1.5 \mathrm{~m}$ \\
\hline \multicolumn{2}{|l|}{ Time Stepping } & First-order \\
\hline \multicolumn{2}{|c|}{ Time-Step Maximum } & $300 \mathrm{~s}$ \\
\hline \multirow{2}{*}{ Convergence } & Residual Norm & 0.001 \\
\hline & Increment Norm & 0.01 \\
\hline
\end{tabular}

Figure 13. Material designations.

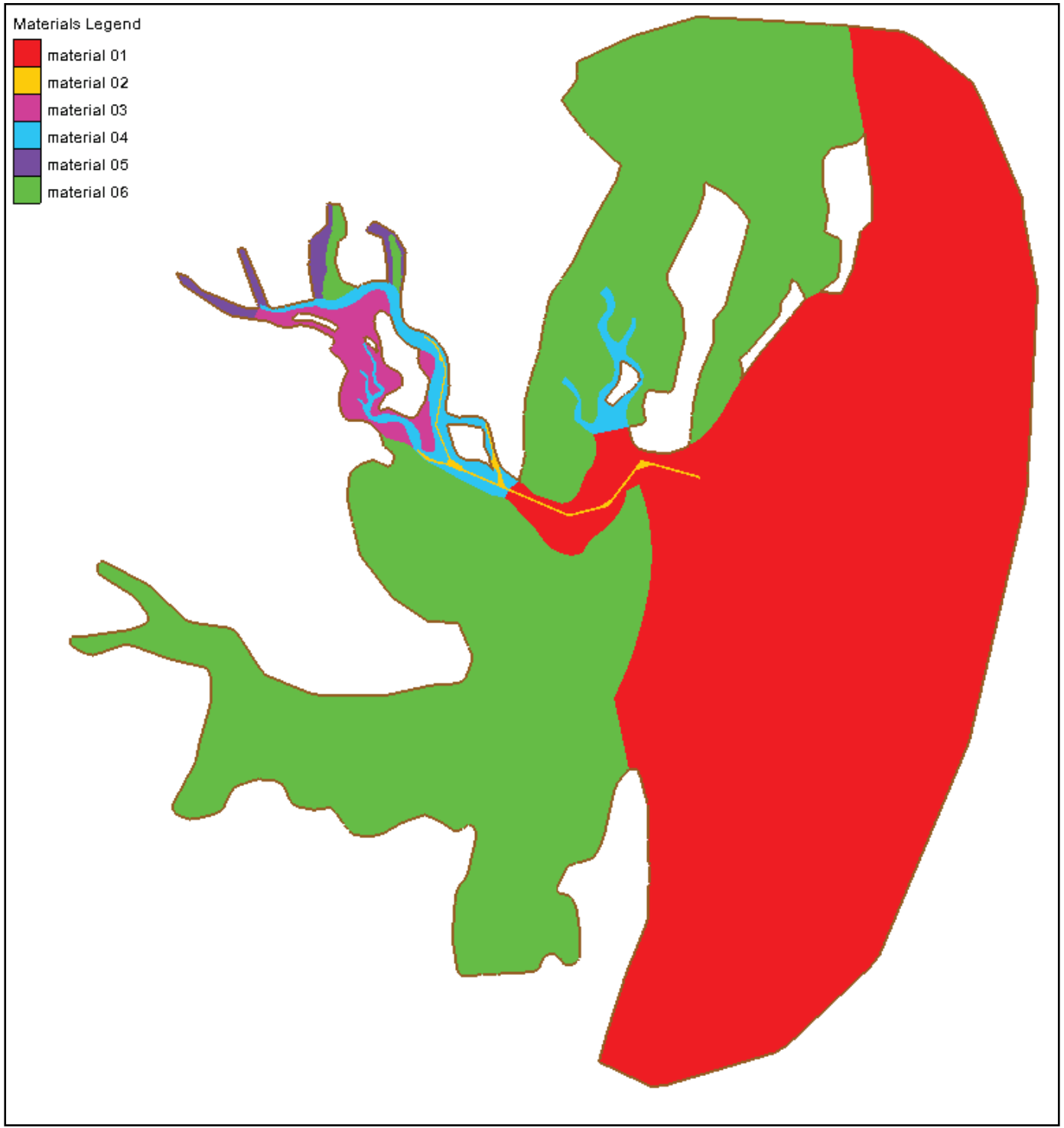


Table 2. Material parameters.

\begin{tabular}{|c|l|l|l|}
\hline$\#$ & Friction Type & Value & Wind Formulation \\
\hline $\mathbf{1}$ & Equivalent Roughness Height & $0.0035 \mathrm{~m}$ & Wu (1982) \\
\hline $\mathbf{2}$ & Equivalent Roughness Height & $0.005 \mathrm{~m}$ & $\mathrm{Wu}(1982)$ \\
\hline $\mathbf{3}$ & Equivalent Roughness Height & $0.006 \mathrm{~m}$ & Teeter (2002) \\
\hline $\mathbf{4}$ & Equivalent Roughness Height & $0.006 \mathrm{~m}$ & $\mathrm{Wu} \mathrm{(1982)}$ \\
\hline $\mathbf{5}$ & OFF & \multicolumn{3}{|l}{} \\
\hline $\mathbf{6}$ & Equivalent Roughness Height & $0.006 \mathrm{~m}$ & Teeter (2002) \\
\hline
\end{tabular}




\section{Model/Field Comparison}

The model is calibrated/validated by comparing to measured field data from July 2019. This is a limited validation effort such that the model is suitable for ship simulation. A more detailed validation period is necessary to utilize this model for a wider range of conditions and parameters. The model domain extents, mesh resolution, bed roughness, and tidal boundary shift were adjusted, within a physically reasonable range, to get the best match to the field data - from the CHL data collection effort and from publicly accessible data websites.

\subsection{Field data collection}

CHL performed a 13-hr field data collection effort in July 2019 at six transects to collect discharge and velocity measurements from the inlet to locations upstream. Figure 14 shows the location of the transects within the model domain. 
Figure 14. Field data collection transects.

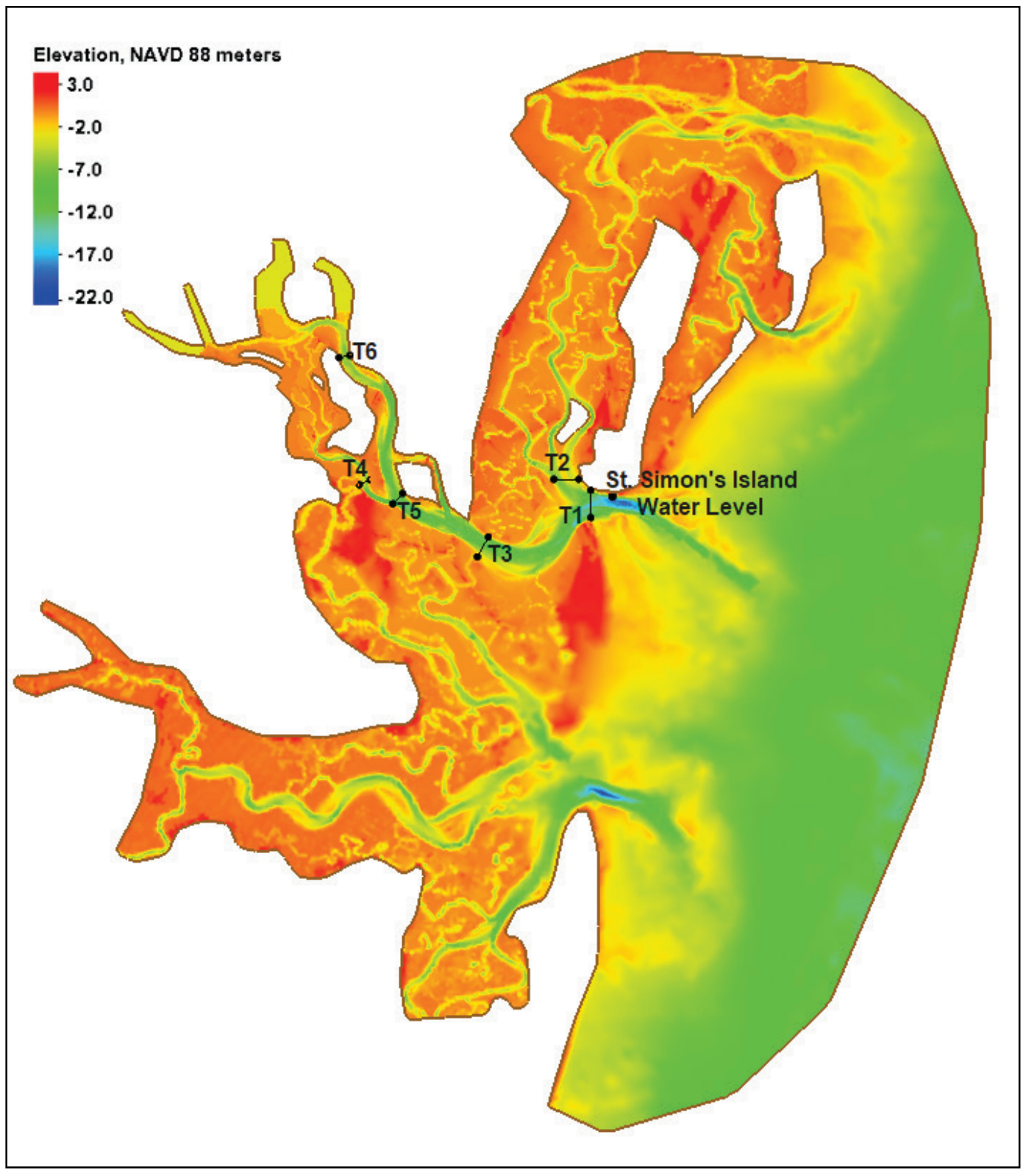

\subsection{Hydrodynamic comparisons}

The model results are compared to water surface elevation at St. Simons Island and discharge at several locations during the 2019 data collection period.

\subsubsection{Water surface elevation}

As noted previously, the tidal boundary water surface elevation was adjusted to match the elevation at St. Simons Island as shown in Figure 15. 
Figure 15. Water surface elevation comparison at St. Simons Island.

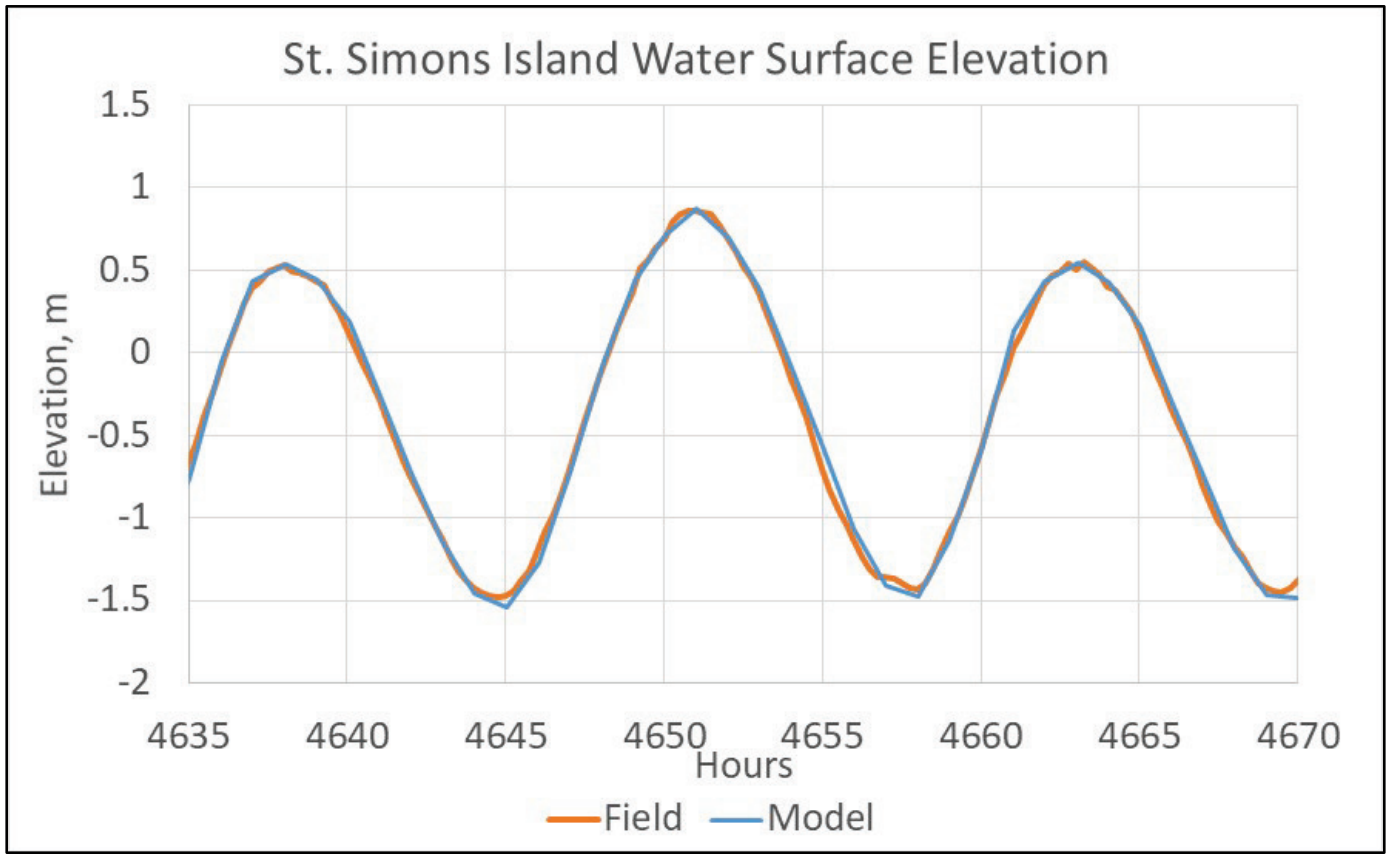

\subsubsection{Discharge}

Discharge comparisons are made at the six transects that were included in the CHL field data collection. Figure 16 through Figure 21 show the time history discharge (positive: flood; negative: ebb) for these locations. The discharge compares well overall. There is some disagreement in the time of arrival of the peak flood at transects 2 and 4. These areas are impacted greatly by shallow backwater flow which may not be defined with enough detail as necessary to correctly reproduce the timing. The model is low on the discharge range at transect 5 and low on the ebb magnitude at transects 4 and 6. Given the good agreement of the model at transect 3, additional connectivity or roughness features in the inland area of the channel may exist beyond what could be defined in the model. Even with these differences, the model is reproducing the dynamics of the field and is suitable to for use in ship simulation analysis. 
Figure 16. Discharge comparison at transect 1.

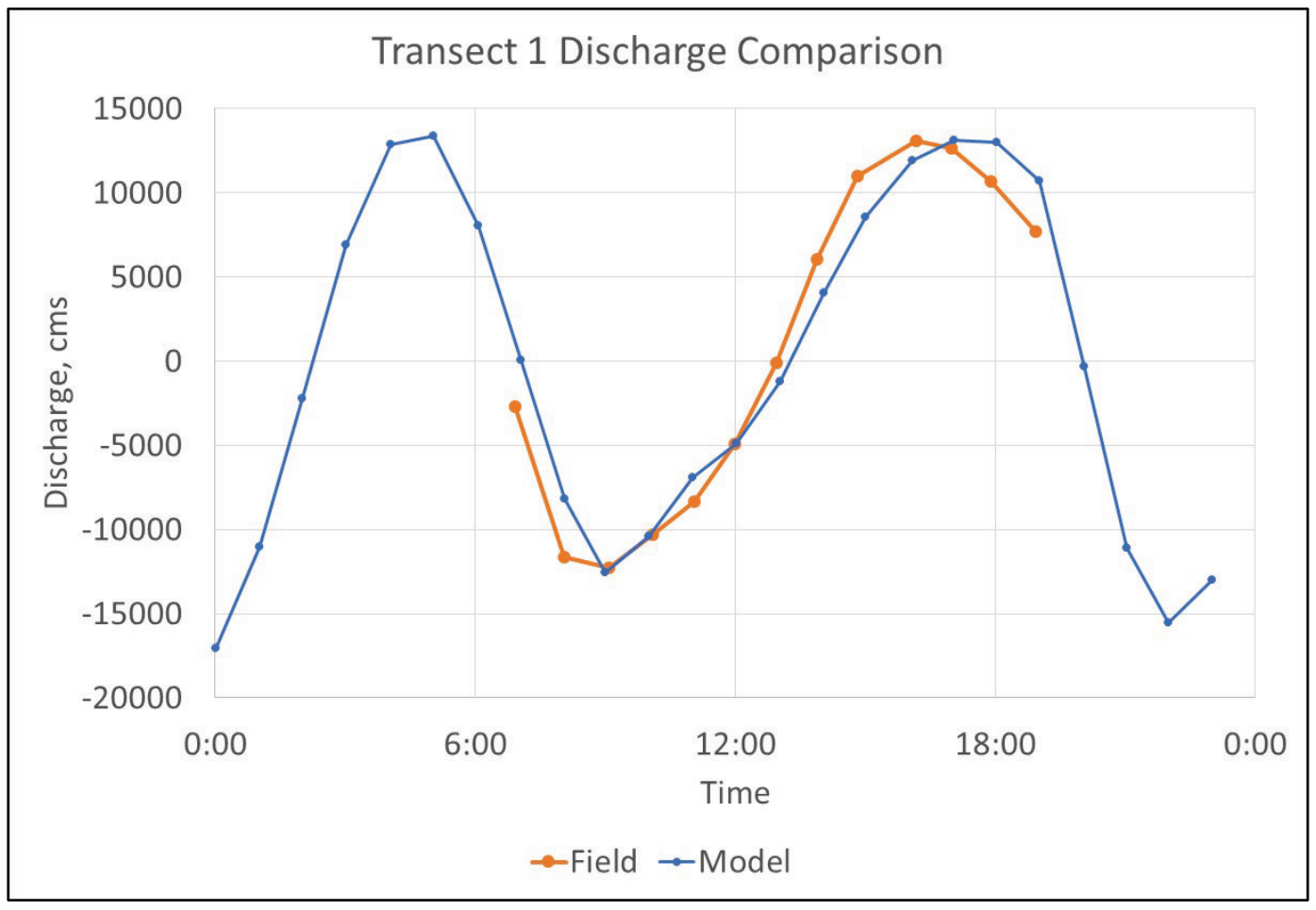

Figure 17. Discharge comparison at transect 2.

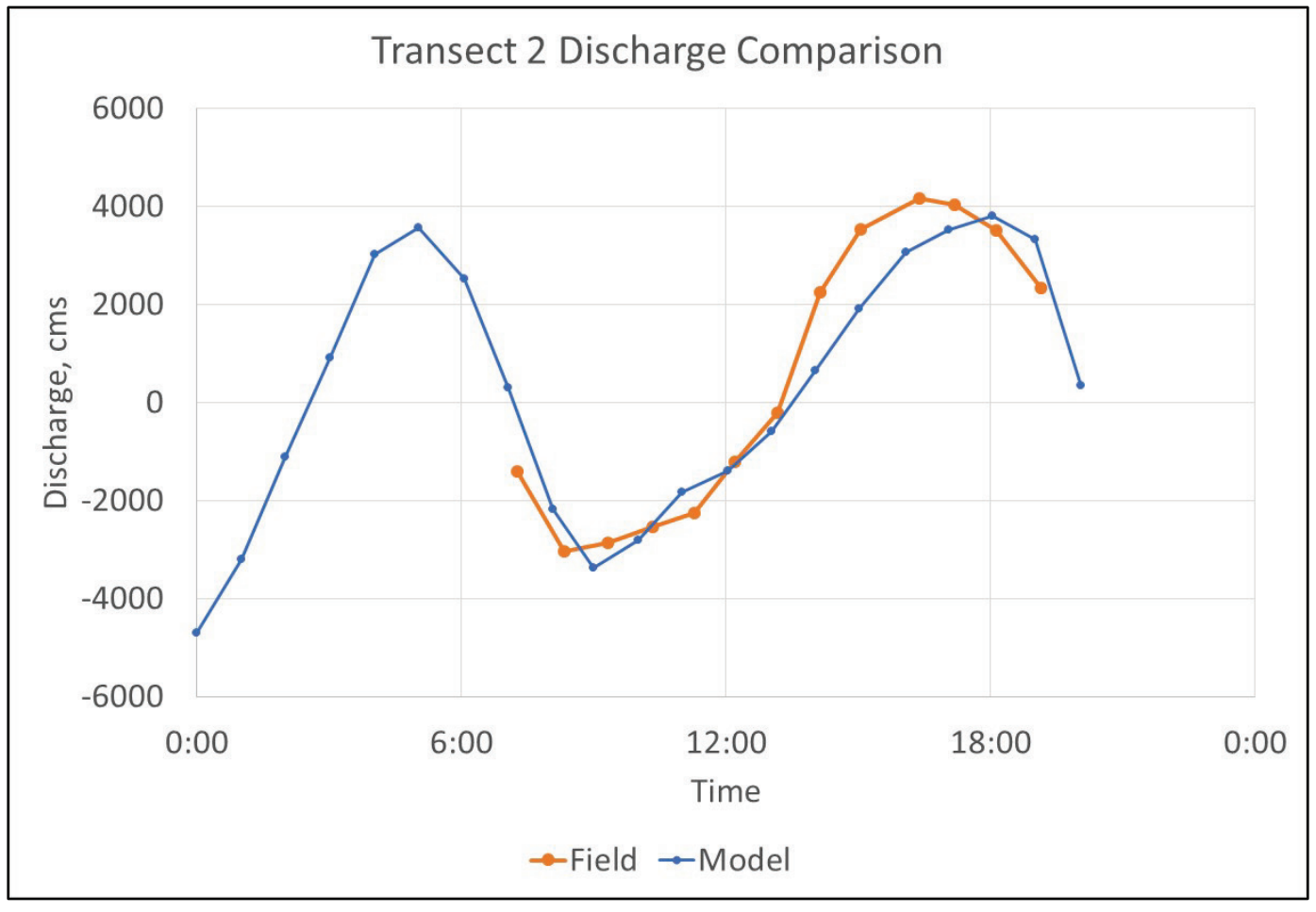


Figure 18. Discharge comparison at transect 3.

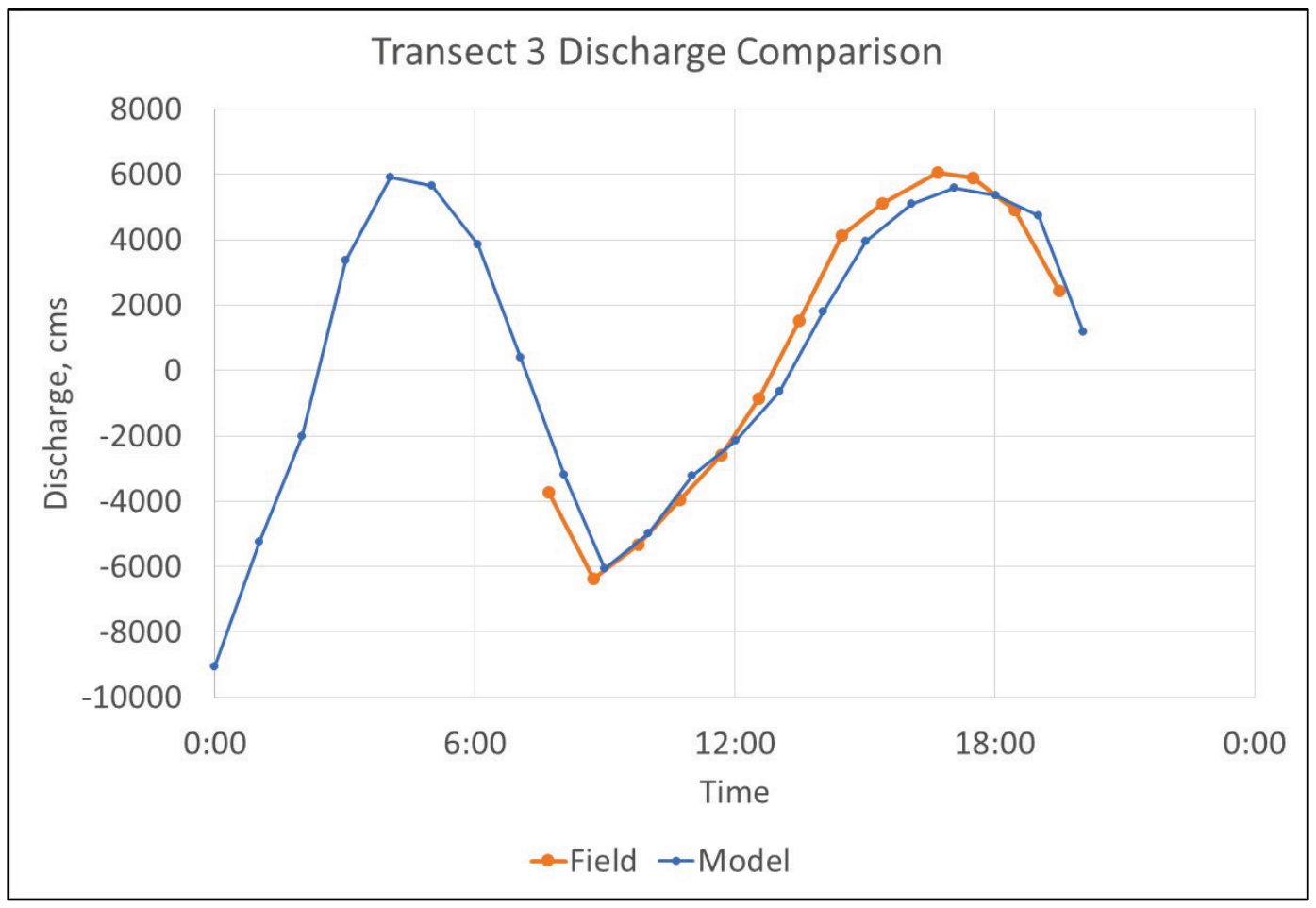

Figure 19. Discharge comparison at transect 4.

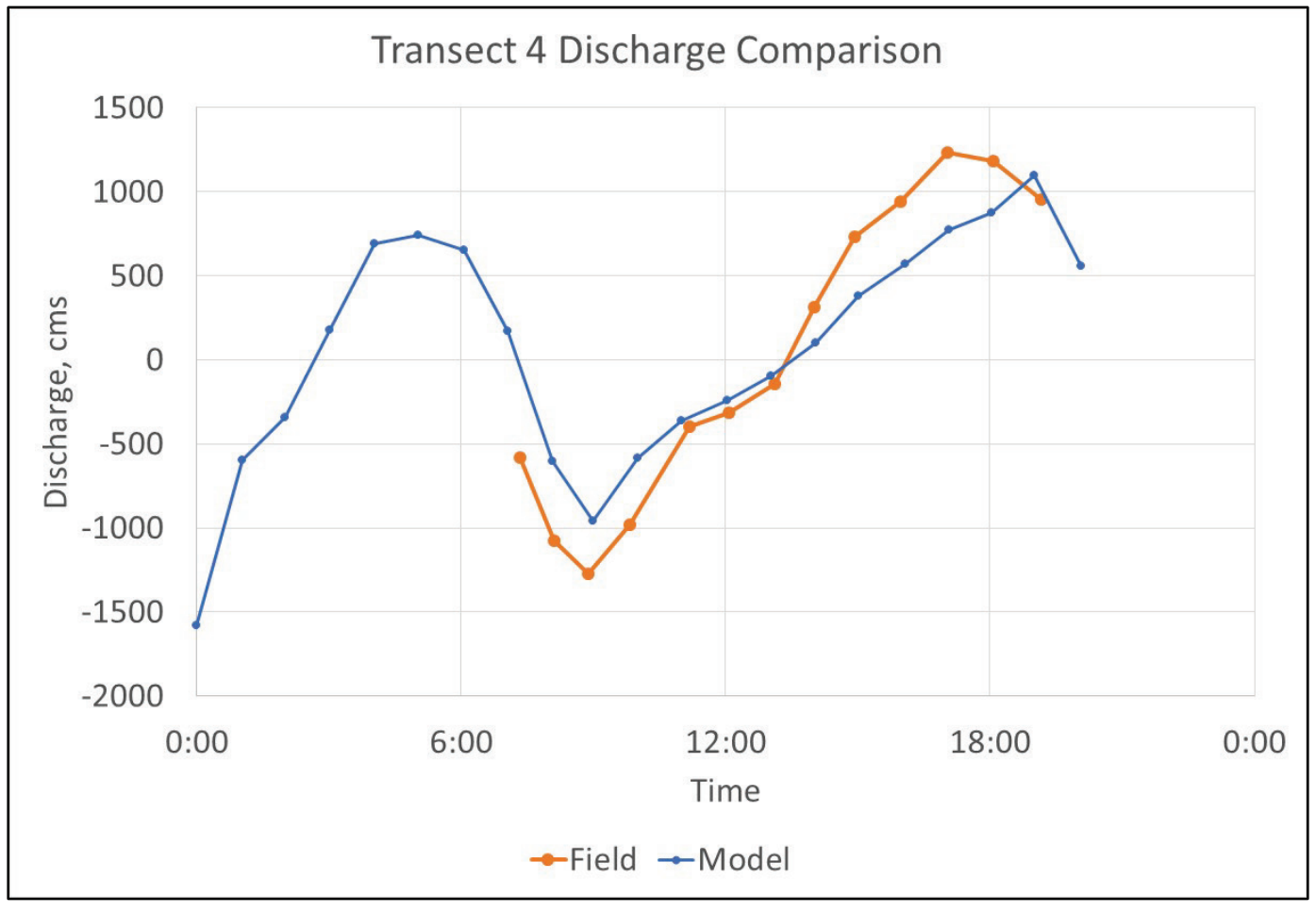


Figure 20. Discharge comparison at transect 5.

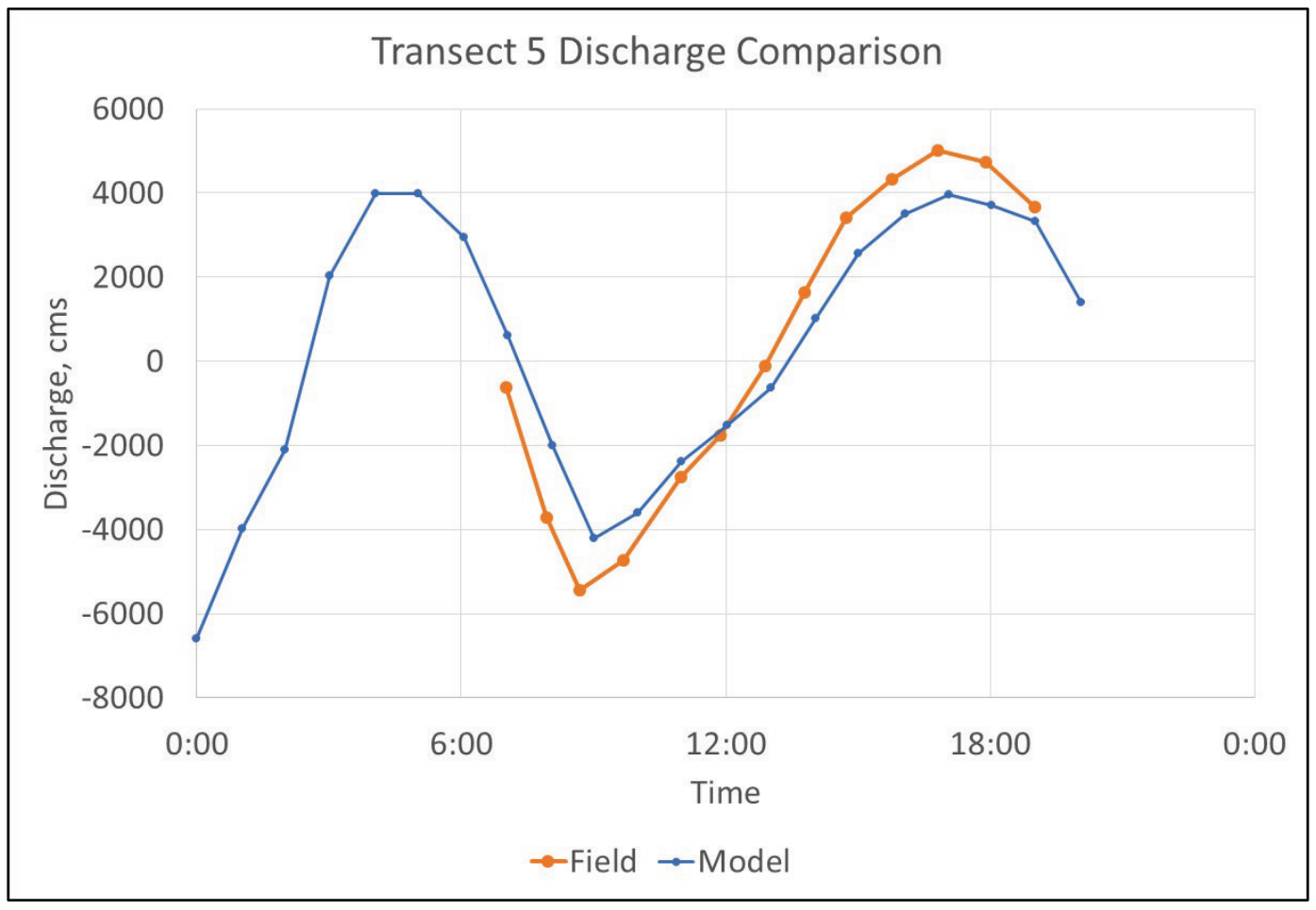

Figure 21. Discharge comparison at transect 6.

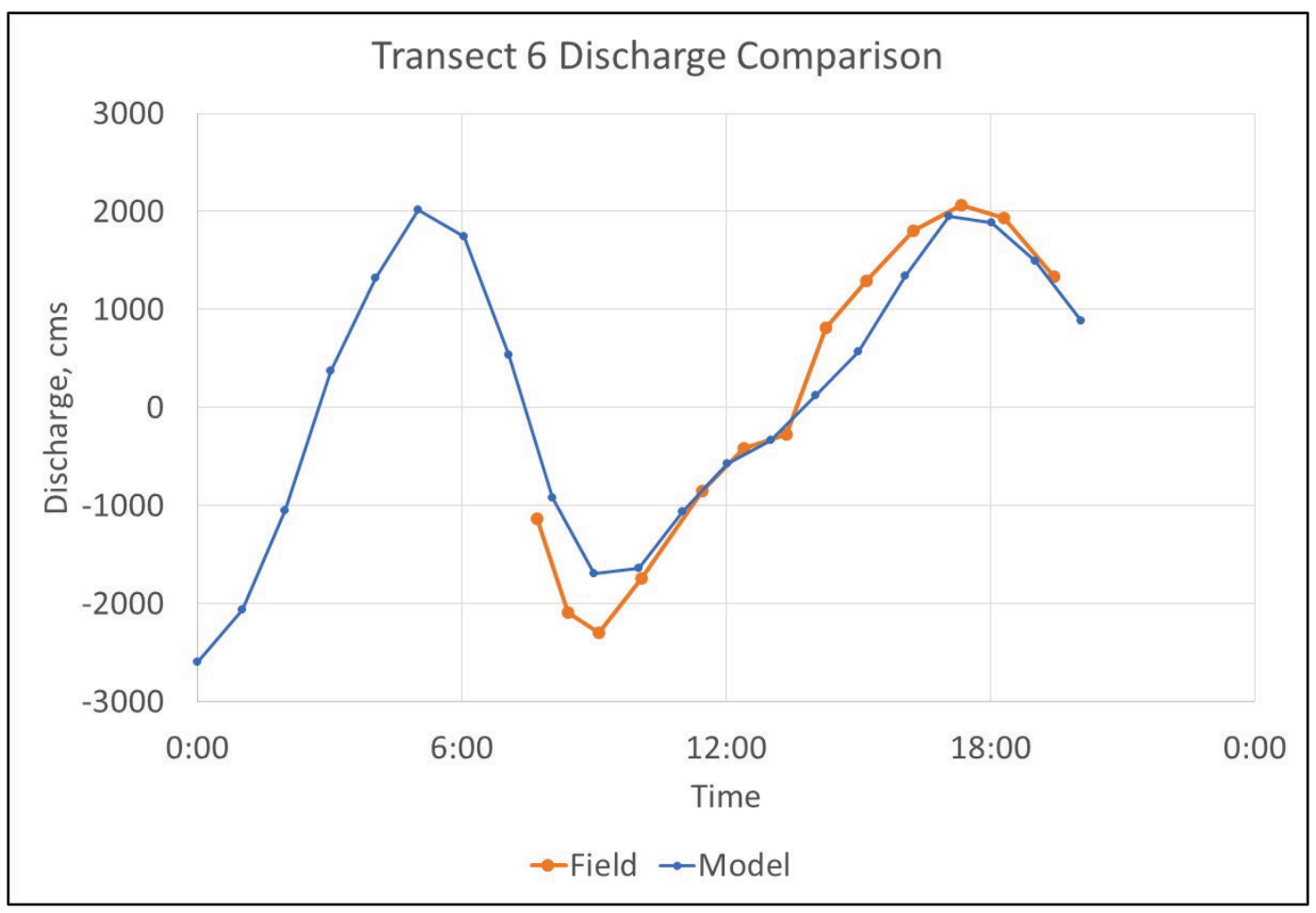




\subsubsection{Velocity}

The velocity magnitude and directions used to compute the field discharge are compared to the model at specific times to determine if the model is reproducing the field velocity patterns. For ship simulation, a single flood and ebb time solution is used, making an accurate representation of the velocity pattern a critical validation step since the velocity direction impacts how the vessel moves in the flow field. Figure 22 through Figure 33 show the flood and ebb velocity comparisons for the six transects. The field-collected velocity direction is shown by the red arrows and the model-computed direction by the black arrows. The vectors are scaled to magnitude. The contours show model velocity magnitude between $o$ and $3 \mathrm{~m} / \mathrm{s}$.

Figure 22. Transect 1 flood direction velocity.

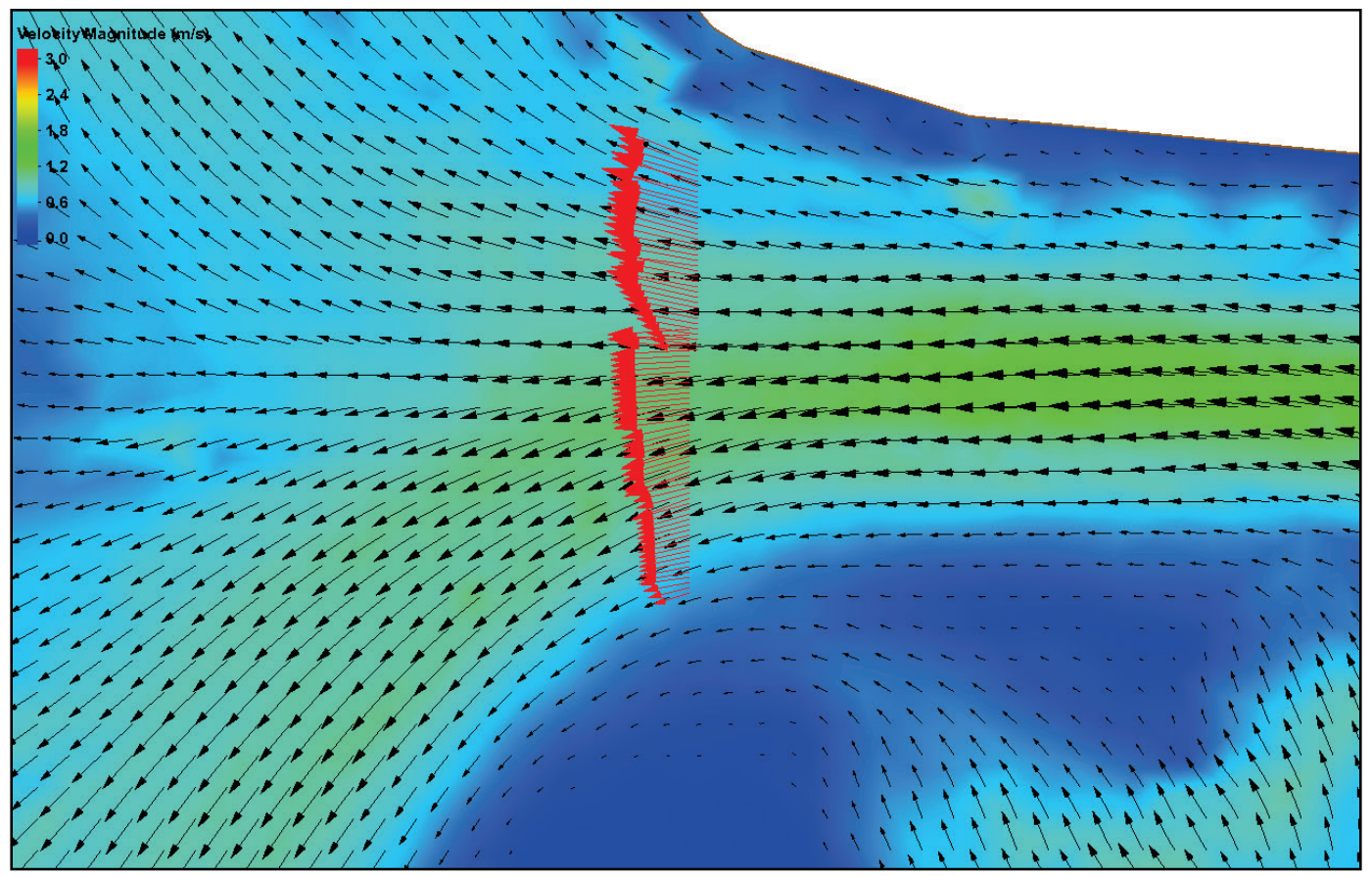


Figure 23. Transect 1 ebb direction velocity.

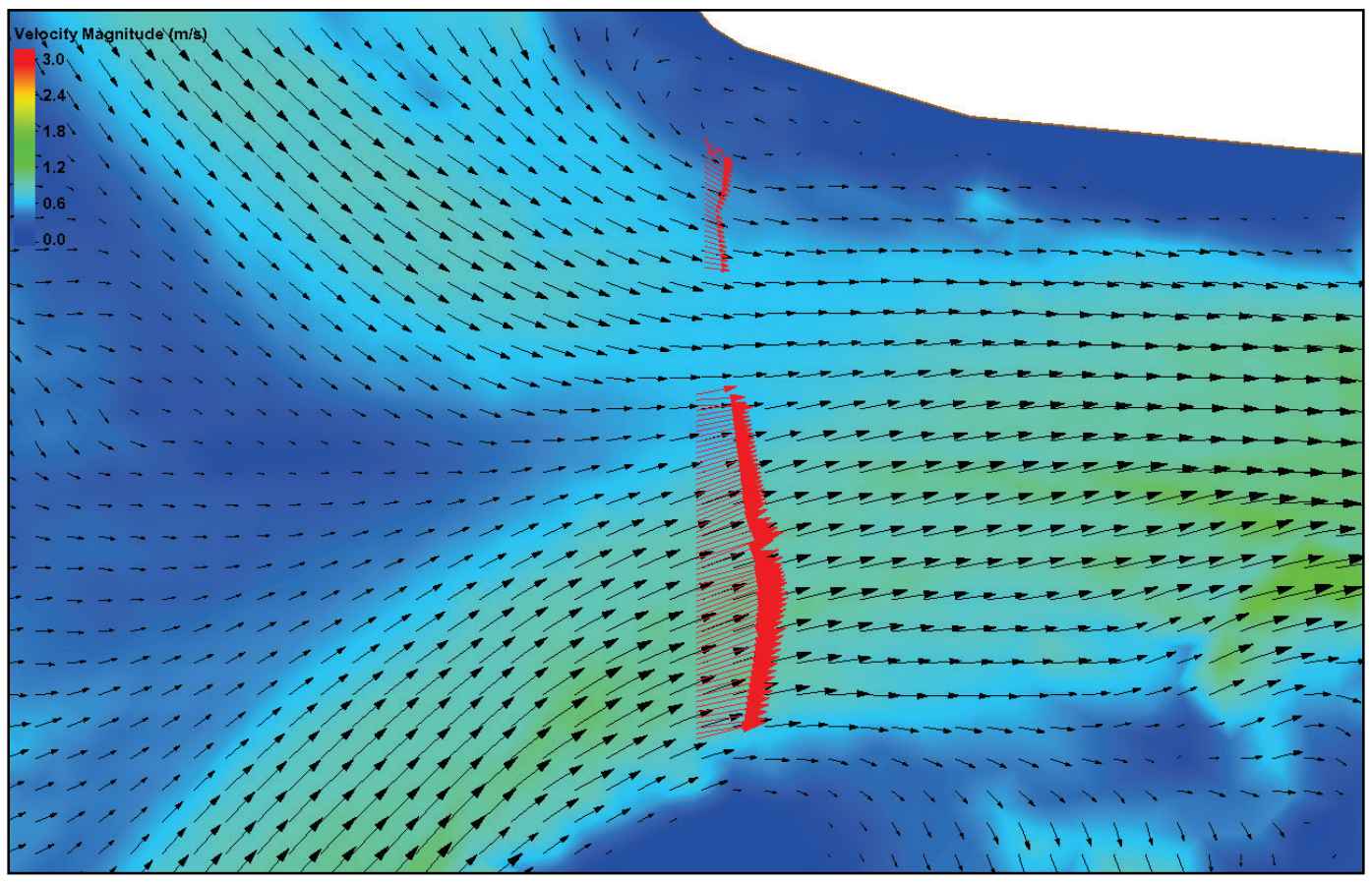

Figure 24. Transect 2 flood direction velocity.

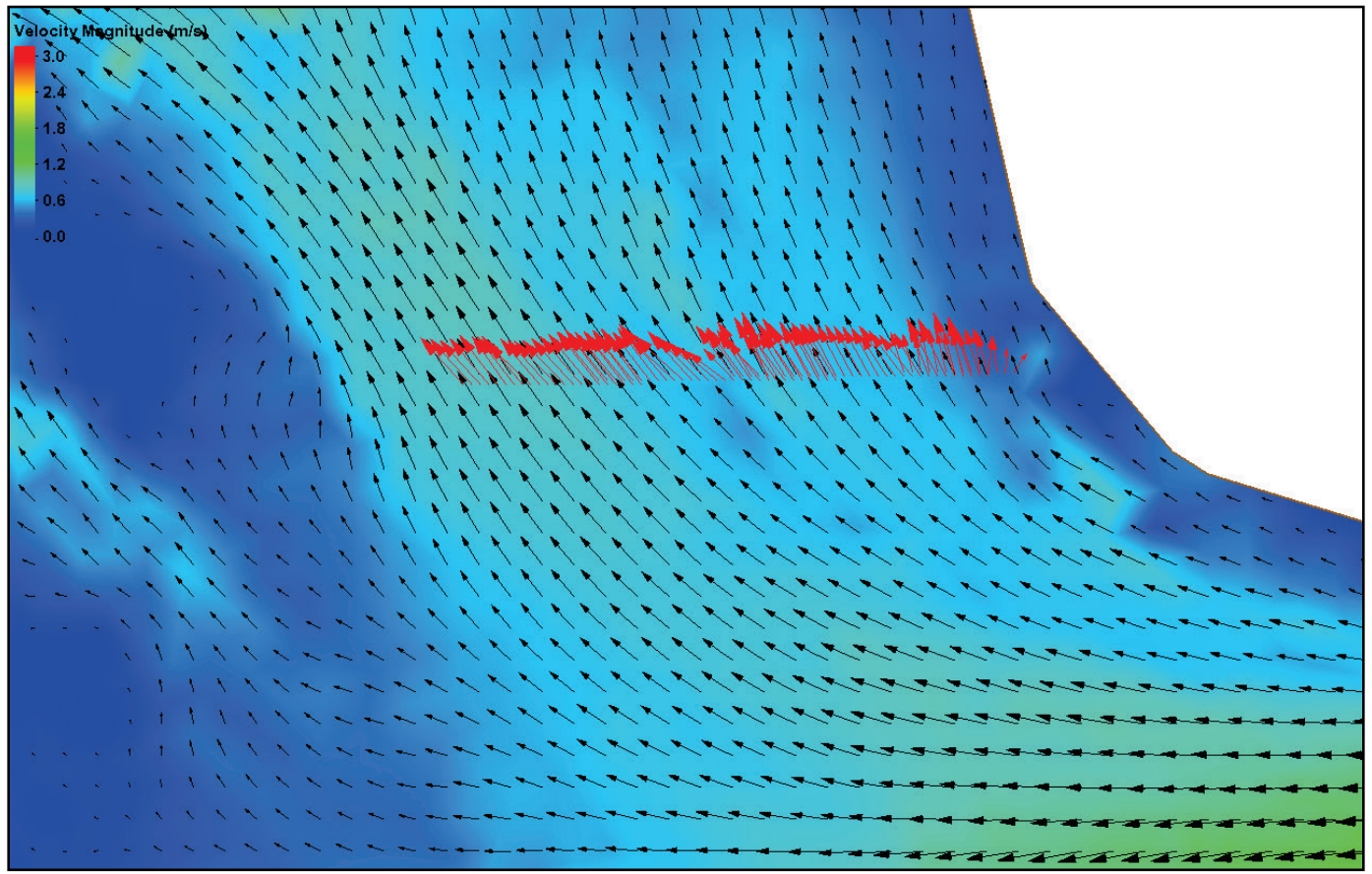


Figure 25. Transect 2 ebb direction velocity.

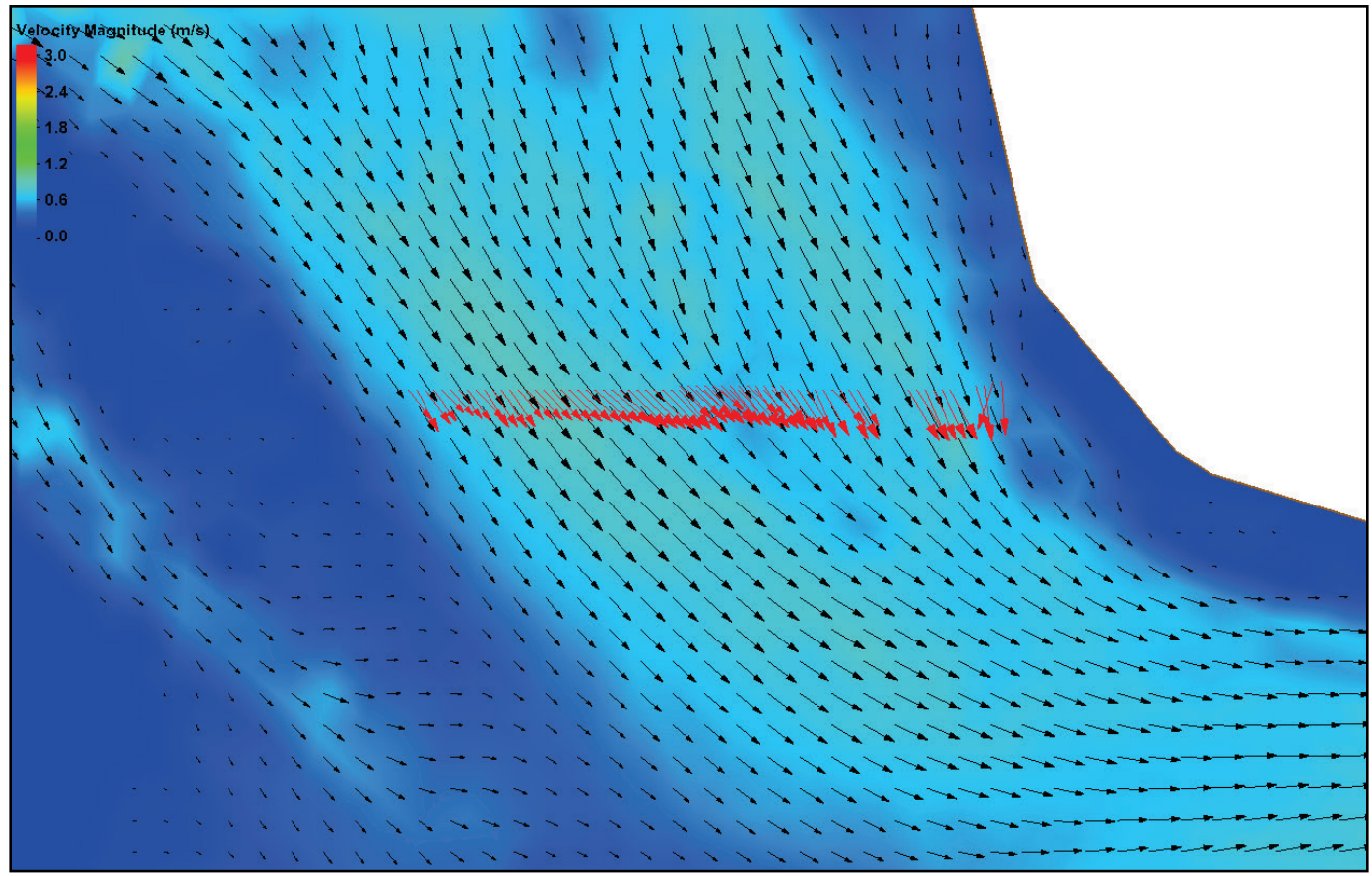

Figure 26. Transect 3 flood direction velocity.

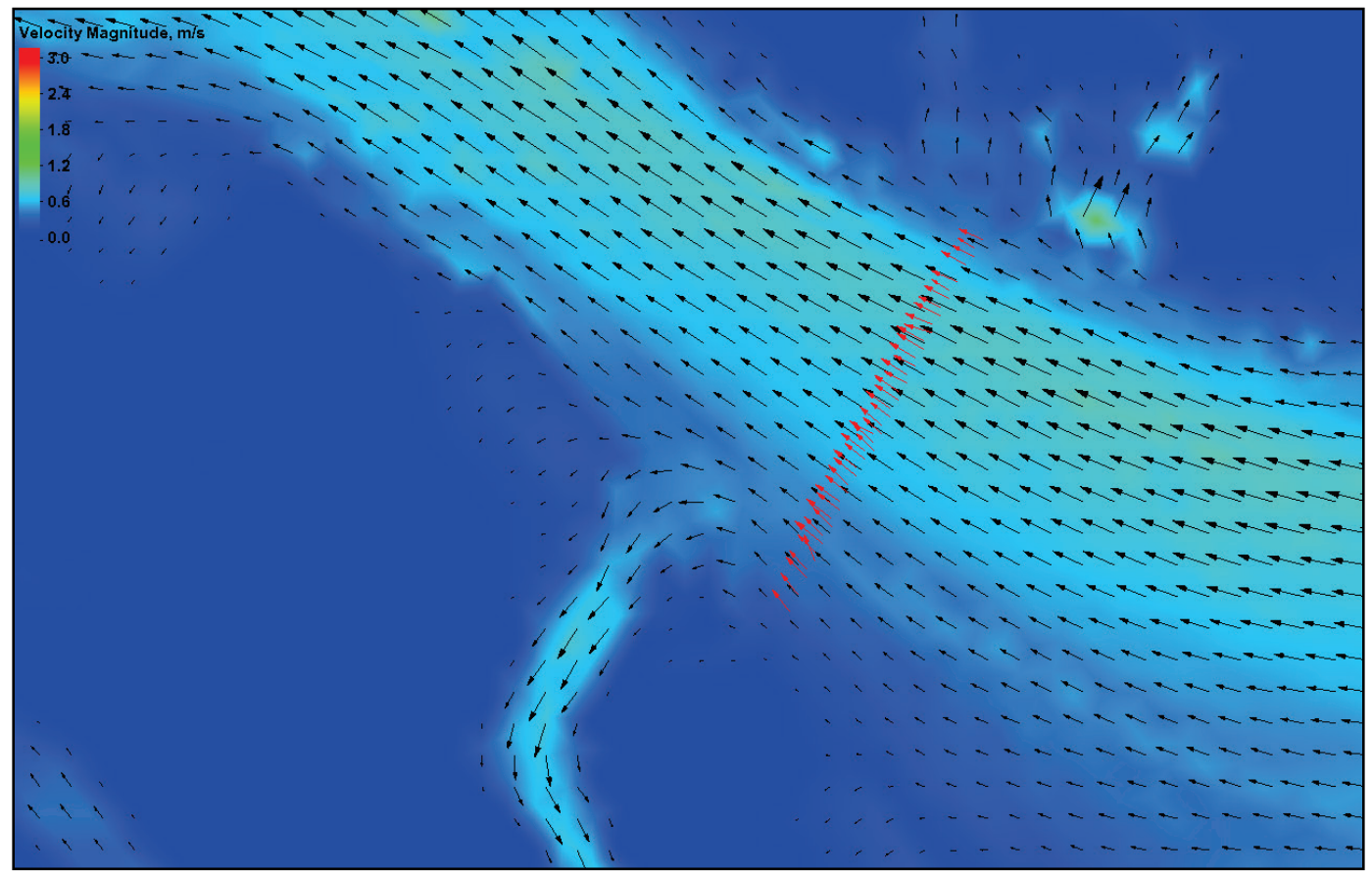


Figure 27. Transect 3 ebb direction velocity.

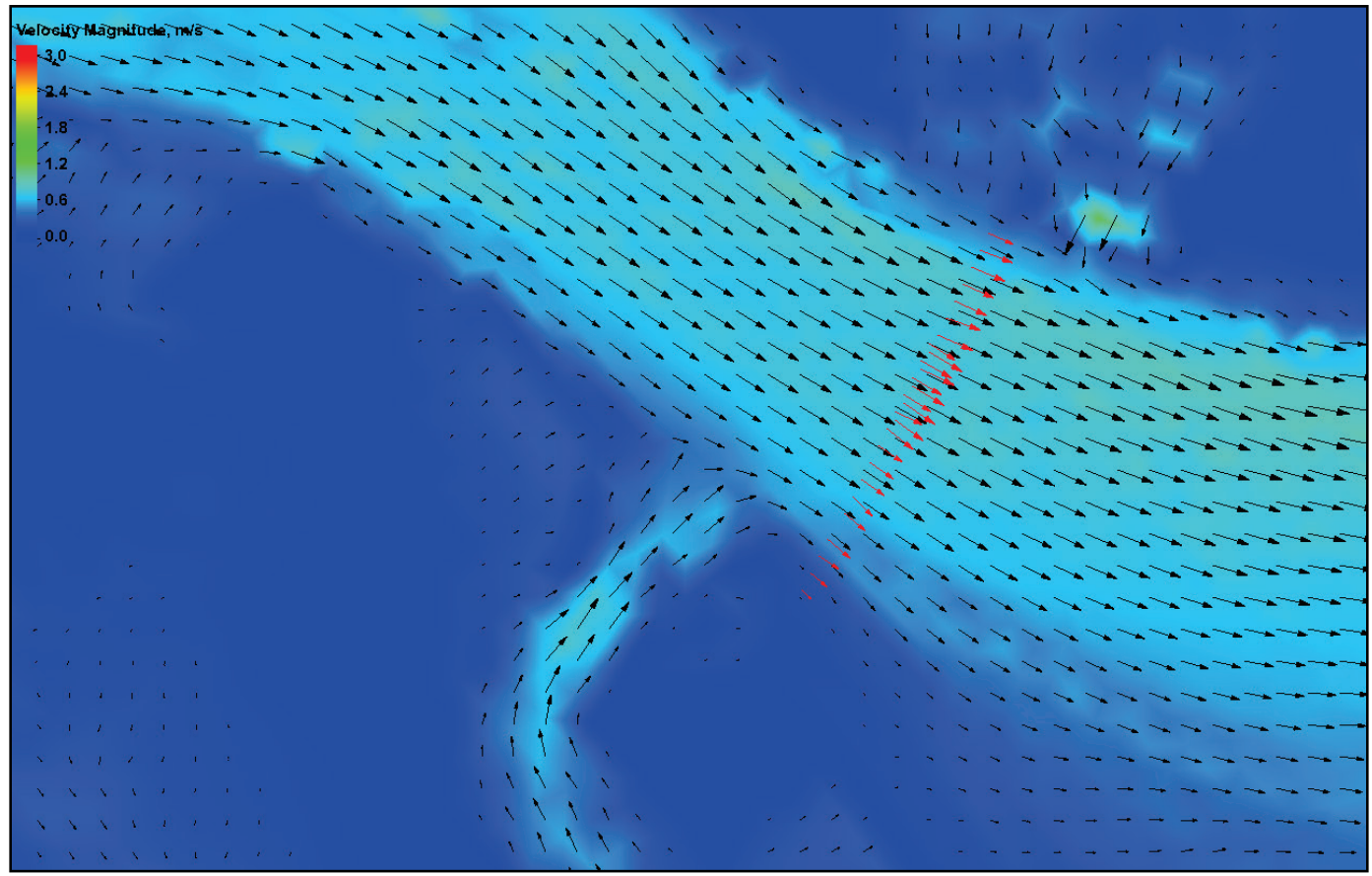

Figure 28. Transect 4 flood direction velocity.

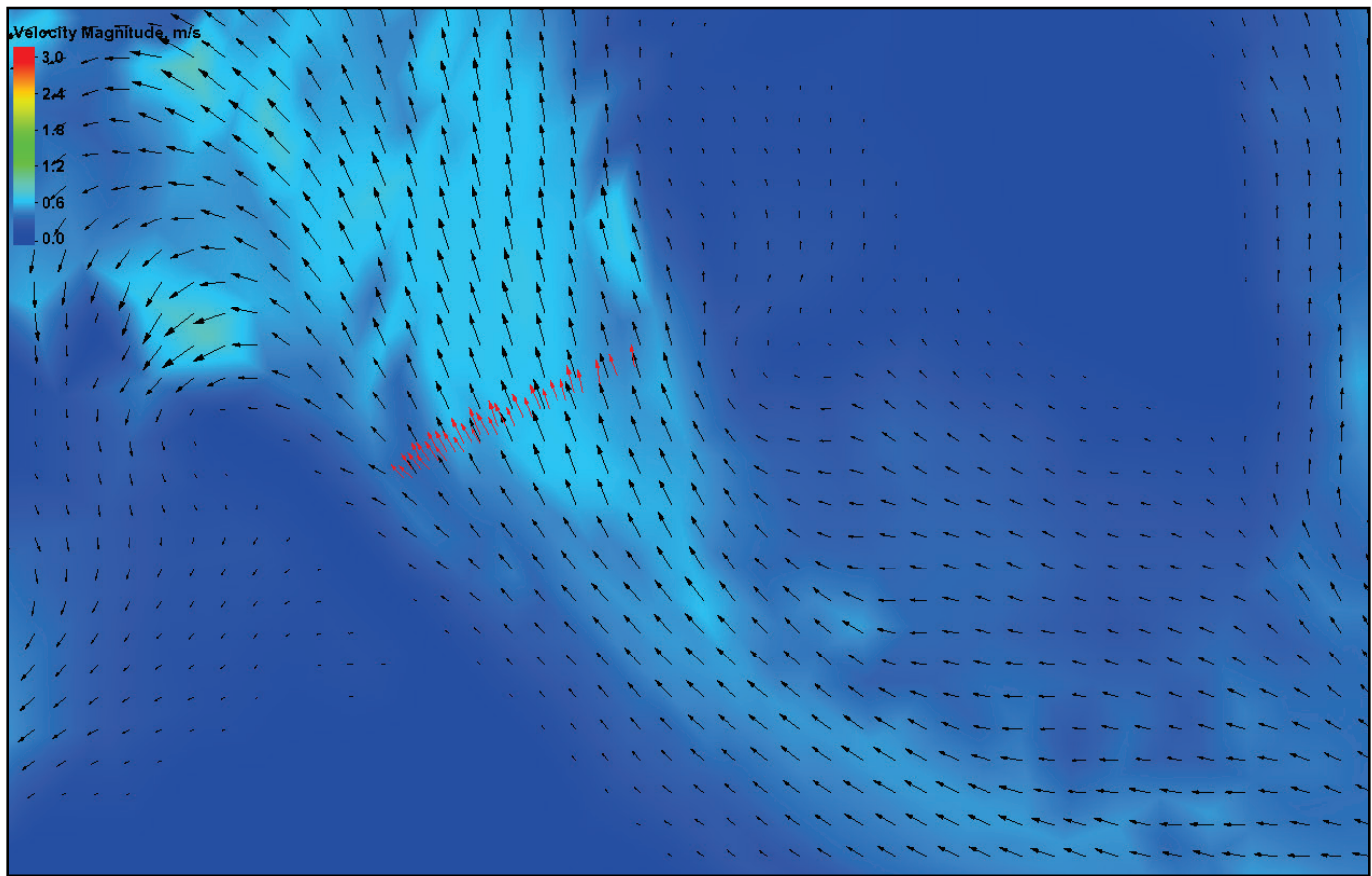


Figure 29. Transect 4 ebb direction velocity.

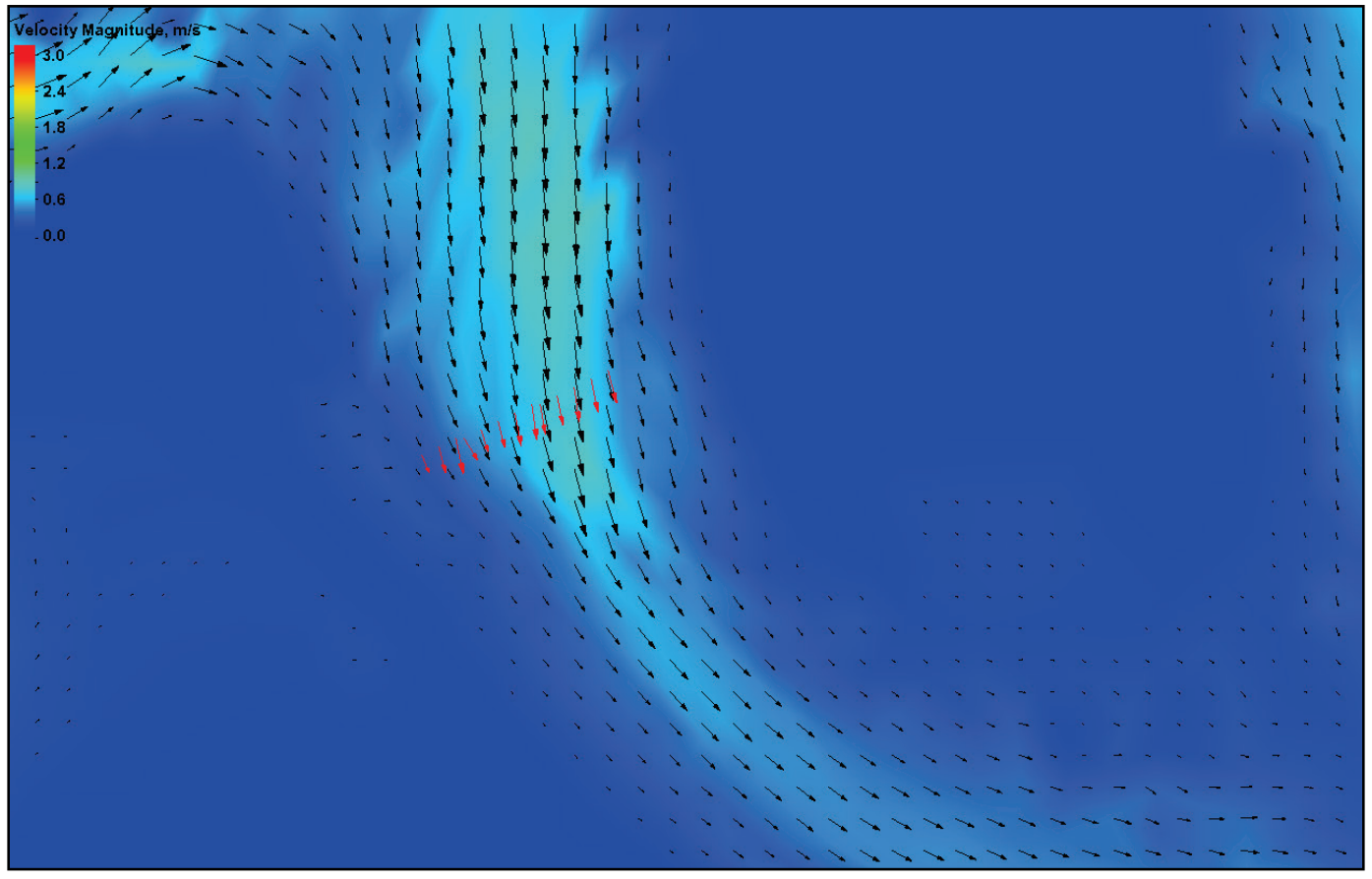

Figure 30. Transect 5 flood direction velocity.

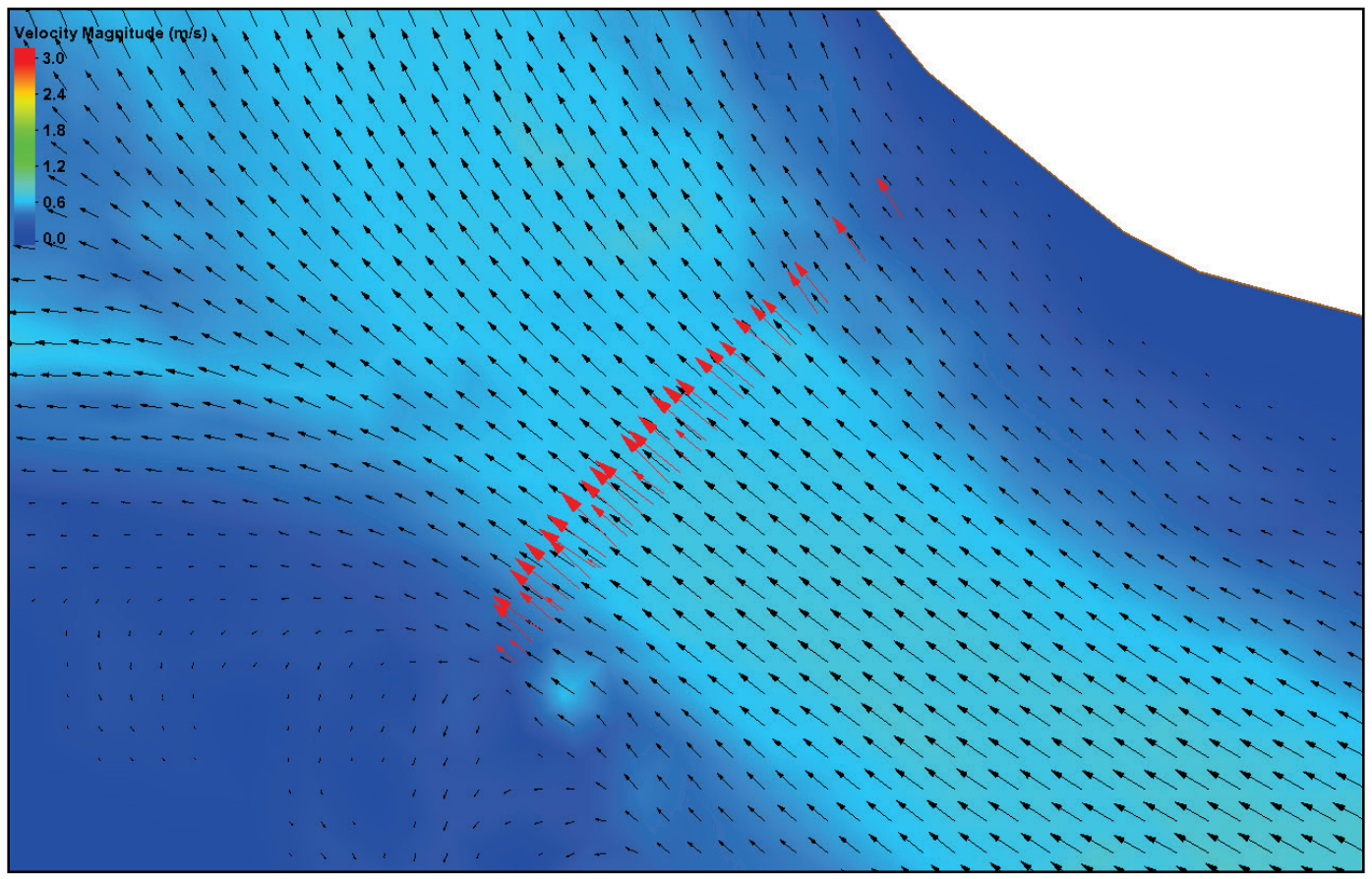


Figure 31. Transect 5 ebb direction velocity.

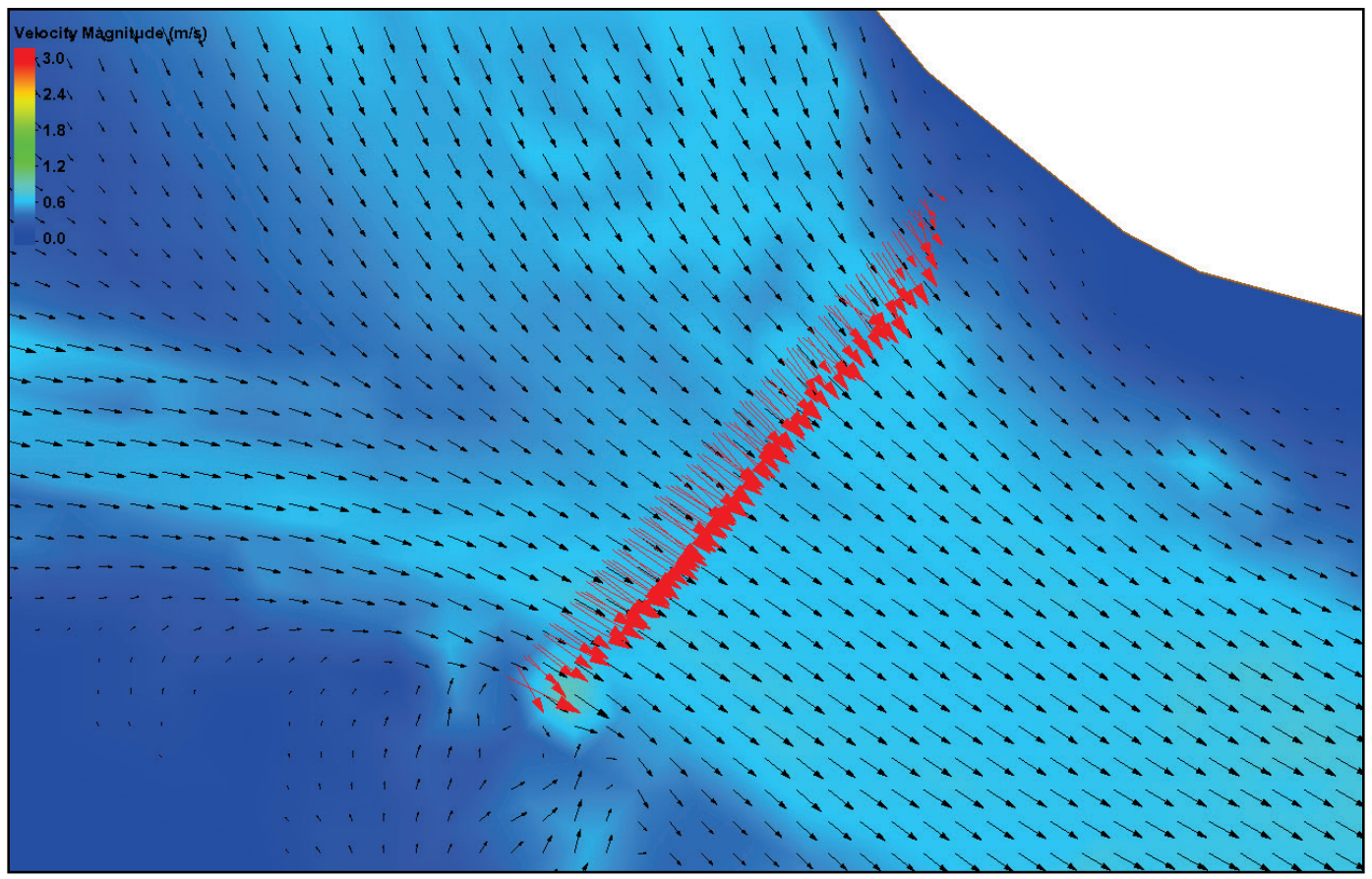

Figure 32. Transect 6 flood direction velocity.

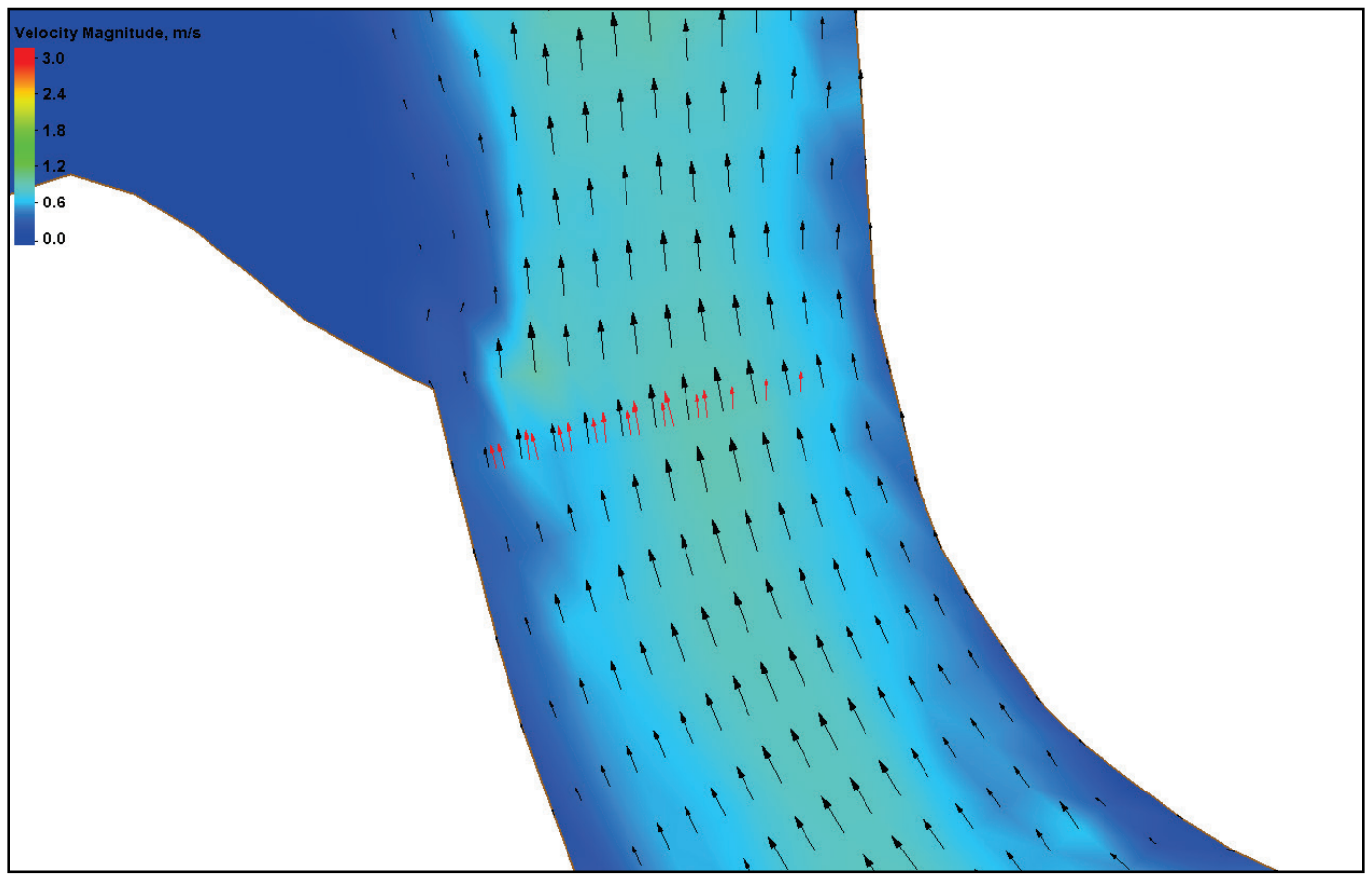


Figure 33. Transect 6 ebb direction velocity.

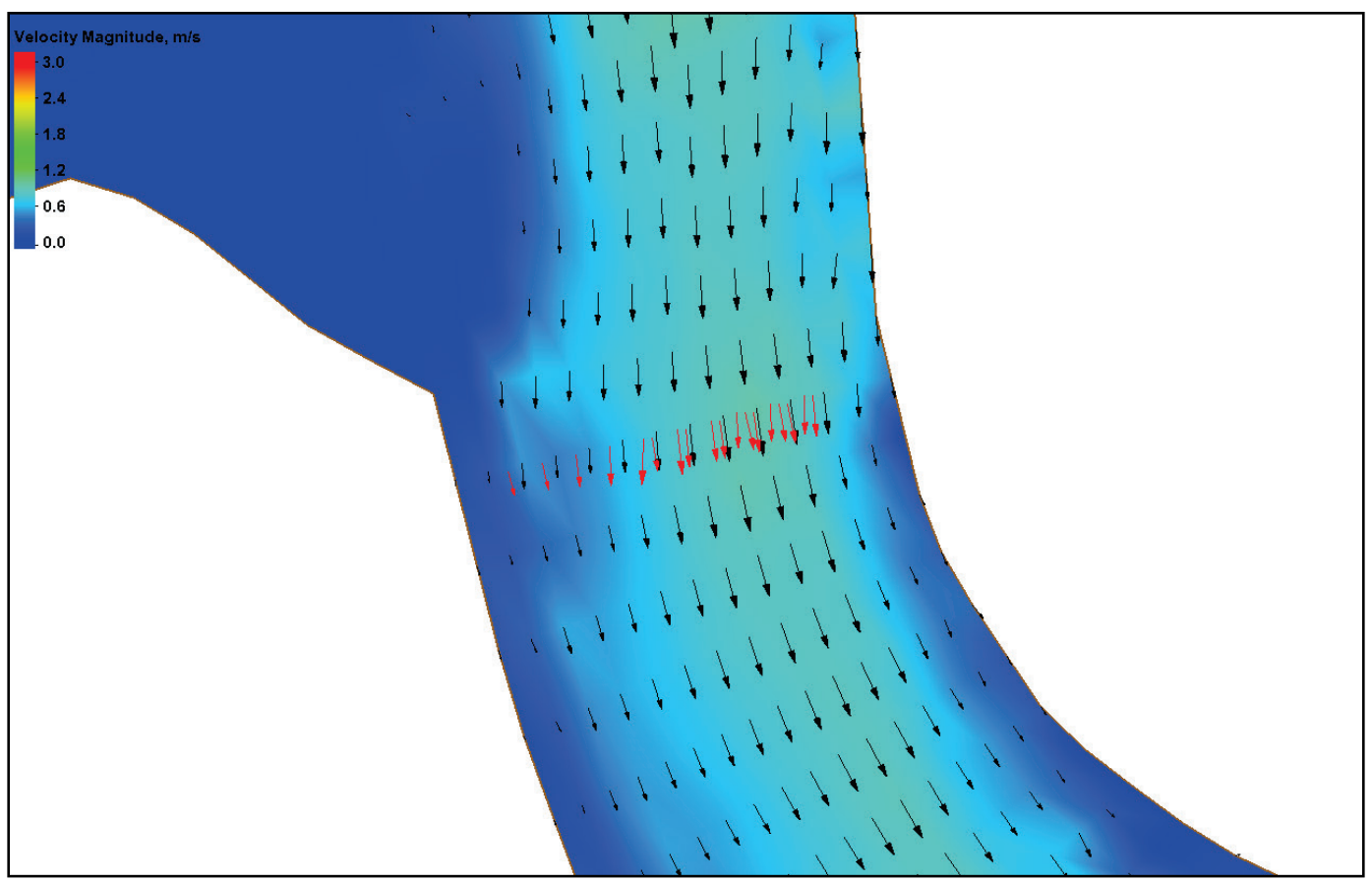




\section{Conclusions}

A 2D AdH model was developed and compared to field data for use in ship simulation at ERDC. The model was built to include all areas impacting the Brunswick navigation channel and driven with tides and winds. Bed roughness and tidal storage were adjusted during the model/field comparison. Water surface elevation, discharge, and velocity were used to ensure the model adequately represented the field conditions. Ship simulation uses a single time solution for flood and ebb, making velocity patterns critical to accurate field representation.

The model compares well to the various field datasets. However, the calibration/validation effort was limited by the available data. Although the model is suitable for ship simulation, using it to simulate a longer time period and a range of conditions will require additional data for model/field comparison. 


\section{References}

Bell, Gary L., N. D. Clifton, and D. D. Abraham. 2017. Hydrodynamics in the Morganza Floodway Report 1: Phase 1-Model Development and Calibration. MRG\&P Report No. 13. Vicksburg, MS: US Army Engineer Research and Development Center.

Clifton, N., D. Abraham, and D. Pridal. 2017. Upper and Lower Hamburg Bend 2011 Flood Evaluation on the Missouri River near Hamburg, Iowa. ERDC/CHL TR17-1. Vicksburg, MS: US Army Engineer Research and Development Center.

Guilfoyle Michael P. and Richard A. Fischer. 2011. Managing Dredged Material Placement and Disposal Operations in Relation to Bird/Wildlife Aircraft Strike Hazards (BASH). ERDC TN-DOER-C36. Vicksburg, MS: US Army Engineer Research and Development Center.

Heath, R. E., G. L. Brown, C. D. Little, T. C. Pratt, J. J. Ratcliff, D. Abraham, D. W. Perkey, N. B. Ganesh, S. K. Martin, and D. P. May. 2015. Old River Control Complex Sedimentation Investigation. ERDC/CHL TR-15-8. Vicksburg, MS: US Army Engineer Research and Development Center.

Letter, Joseph V., Jr. and William H. McAnally. 1981. Physical Hydraulic Models: Assessment of Predictive Capabilities, Report 3: Model Study of Shoaling Brunswick Harbor, Georgia. Research Report H-75-3. Vicksburg, MS: US Army Engineer Waterways Experiment Station.

Letter, J. V., G. L. Brown, R. T. McAdory, and T. C. Pratt. 2015. Numerical Modeling of Trinity River Shoaling below Wallisville, Texas. ERDC/CHL TR-15-1. Vicksburg, MS: US Army Engineer Research and Development Center.

McAlpin, T. O., G. Savant, G. L. Brown, S. J. Smith, and R. S. Chapman. 2013. "Hydrodynamics of Knik Arm: Modeling Study." Journal of Waterway, Port, Coastal, and Ocean Engineering 139(3).

Savant, G., R. C. Berger, T. O. McAlpin, and C. J. Trahan. 2014. Three-Dimensional Shallow Water Adaptive Hydraulics (AdH-SW3): Hydrodynamic Verification and Validation. ERDC/CHL TR-14-7. Vicksburg, MS: US Army Engineer Research and Development Center.

Savant, G., and R. C. Berger. 2015. Three-Dimensional Shallow Water Adaptive Hydraulics (AdH-SW3) Validation: Galveston Bay Hydrodynamics and Salinity Transport. ERDC/CHL TR-15-3. Vicksburg, MS: US Army Engineer Research and Development Center.

Sharp, J. A., C. D. Little, G. L. Brown, T. C. Pratt, R. E. Heath, L. C. Hubbard, F. Pinkard, S. K. Martin, N. D. Clifton, D. W. Perkey, and N. B. Ganesh. 2013. West Bay Sediment Diversion Effects. ERDC/CHL TR-13-15. Vicksburg, MS: US Army Engineer Research and Development Center. 
Tate, J. N., J. P. McKinney, T. C. Pratt, F. C. Carson, M. W. Tubman, G. L. Brown, K. M. Barry, R. T. McAdory, and M. J. Briggs. 2009. Salinas de San Pedro (Cabrillo) Wetland Restoration Project. Volume 1, Main Text. ERDC/CHL TR-09-14. Vicksburg, MS: US Army Engineer Research and Development Center.

Teeter, Allen Michael. 2002. Sediment Transport in Wind-Exposed Shallow, Vegetated Aquatic Systems. Dissertation. Louisiana State University.

Wu, J. 1982. "Wind-Stress Coefficients Over Sea Surface from Breeze to Hurricane." Journal of Geophysical Research 87(C12): 9704-9706. 


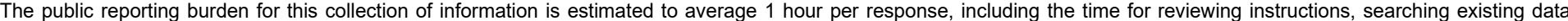

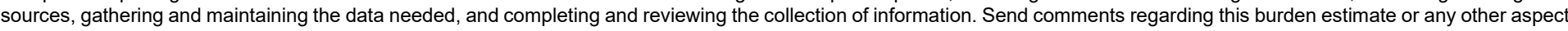

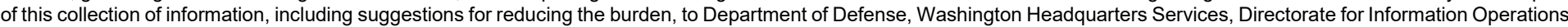

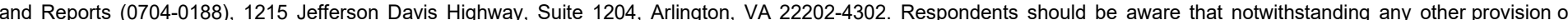
law, no person shall be subject to any penalty for failing to comply with a collection of information if it does not display a currently valid OMB control number. PLEASE DO NOT RETURN YOUR FORM TO THE ABOVE ADDRESS.

\begin{tabular}{l|l|l}
$\begin{array}{l}\text { 1. REPORT DATE } \\
\text { May } 2021\end{array}$ & $\begin{array}{l}\text { 2. REPORT TYPE } \\
\text { Final Report }\end{array}$ & 3. DATES COVERED (FrOm - To)
\end{tabular}

\section{TITLE AND SUBTITLE}

Brunswick Harbor Numerical Model 5a. CONTRACT NUMBER

5b. GRANT NUMBER

5c. PROGRAM ELEMENT NUMBER

5d. PROJECT NUMBER

465055

Jennifer McAlpin and Jason Lavecchia 5e. TASK NUMBER

5f. WORK UNIT NUMBER

8. PERFORMING ORGANIZATION REPORT NUMBER $101 \mathrm{~W}$ York St.

Savannah, GA 31401

USACE District, Savannah (SAS)

\section{PERFORMING}

Coastal and Hydraulics Laboratory

US Army Engineer Research and

Development Center

3909 Halls Ferry Road

Vicksburg, MS 39180-6199

\section{SPONSORING/MONITORING AGENCY NAME(S) AND ADDRESS(ES)}

USACE District, Savannah

Savannah, GA 31401

ERDC/CHL TR-21-6

10. SPONSOR/MONITOR'S ACRONYM(S)

USACE SAS

11. SPONSOR/MONITOR'S REPORT NUMBER(S)

\section{DISTRIBUTION/AVAILABILITY STATEMENT}

Approved for public release; distribution is unlimited.

\section{SUPPLEMENTARY NOTES}

Funding Account Code K6219288, AMSCO Code 465055, MIPR W33SJG92845079

\section{ABSTRACT}

The Brunswick area consists of many acres of estuarine and marsh environments. The US Army Corps of Engineers District, Savannah, requested that the US Army Engineer Research and Development Center, Coastal and Hydraulics Laboratory, develop a validated Adaptive Hydraulics model and assist in using it to perform hydrodynamic modeling of proposed navigation channel modifications. The modeling results are necessary to provide data for ship simulation. The model setup and validation are presented here.

\section{SUBJECT TERMS}

Brunswick River (Ga.), Brunswick (Ga.)—Harbors, Channels (Hydraulic engineering), Hydrodynamics, Inland navigation

16. SECURITY CLASSIFICATION OF:

a. REPORT

Unclassified

\begin{tabular}{l|l|} 
b. ABSTRACT & c. THIS PAGE \\
Unclassified & Unclassified
\end{tabular}

17. LIMITATION OF ABSTRACT

SAR
18. NUMBER

OF

PAGES

38 19a. NAME OF RESPONSIBLE PERSON Jennifer McAlpin

19b. TELEPHONE NUMBER (Include area code) 601-634-2511 